\title{
OPERATION OF HYDROLOGIC DATA COLLECTION STATIONS BY THE U.S. GEOLOGICAL SURVEY IN 1983
}

By Alberto Condes de la Torre

U.S. GEOLOGICAL SURVEY

Open-File Report 83-862

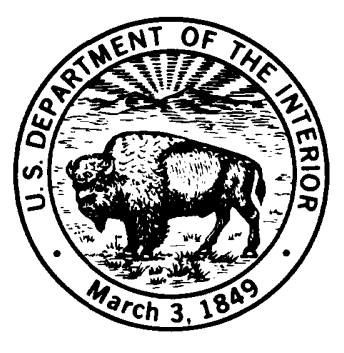




\section{UNITED STATES DEPARTMENT OF THE INTERIOR \\ WILLIAM P. CLARK, Secretary}

GEOLOGICAL SURVEY

Dallas L. Peck, Director

For additional information write to:

Chief Hydrologist

U.S. Geological Survey

405 National Center

12201 Sunrise Valley Drive

Reston, Virginia 22092
Copies of this report can

be purchased from:

Open-File Services Section Western Distribution Branch

Box 25425, Federal Center

Denver, Colorado 80225

(Telephone: (303) 234-5888) 


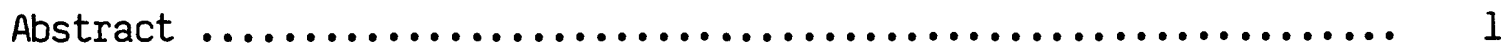

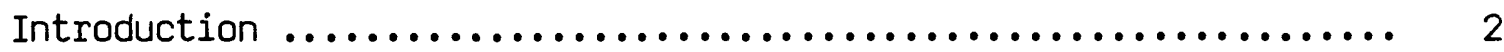

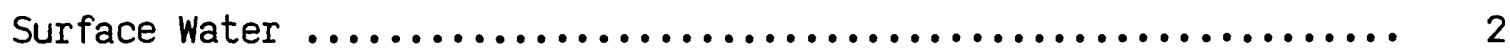

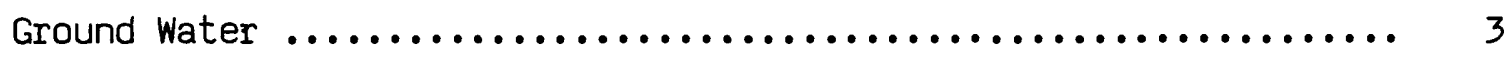

Precipitation $\ldots \ldots \ldots \ldots \ldots \ldots \ldots \ldots \ldots \ldots \ldots \ldots \ldots \ldots \ldots \ldots \ldots \ldots \ldots$

Summary $\ldots \ldots \ldots \ldots \ldots \ldots \ldots \ldots \ldots \ldots \ldots \ldots \ldots \ldots \ldots \ldots \ldots \ldots \ldots \ldots \ldots \ldots$

References Cited ................................... 29

FIGURES

Figure 1. Number of stations, by State, at which surface-water discharge data were collected in fiscal year $1983 \ldots . . .5$

2. Number of continuous surface-water discharge stations and sources of funding support, fiscal year $1983 \ldots \ldots .66$

3. Number of partial record surface-water discharge stations and sources of funding support, fiscal

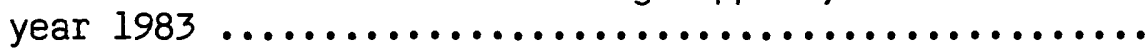

4. Number of stations, by State, at which stage data only were collected on streams in fiscal year 1983 ........

5. Number of continuous surface-water stage only stations on streams and sources of funding support, fiscal

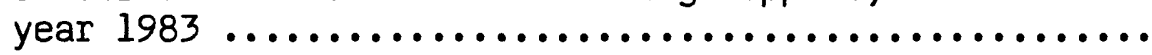

6. Number of partial record surface-water stage only stations on streams and the sources of funding support, fiscal year 1983

7. Number of stations, by State, at which stage only was collected on lakes and reservoirs in fiscal year 1983 ..

8. Number of continuous surface-water stage only stations on lakes and reservoirs and the sources of funding support, fiscal year 1983

9. Number of partial record surface-water stage only stations on lakes and reservoirs and the sources of funding support, fiscal year 1983 
Figure 10. Number of stations, by State, at which surface-waterquality data were collected in fiscal year $1983 \ldots \ldots . .14$

11. Number of continuous surface-water-quality stations and sources of funding support, fiscal year 1983 .......

12. Number of scheduled, long term operation surfacewater-quality stations and sources of funding support,

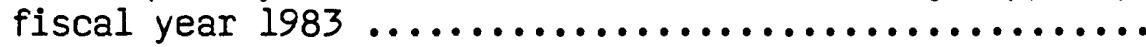

13. Number of short term or project surface-water-quality stations and sources of funding support, fiscal year 1983

14. Number of stations, by State, at which ground-water levels were collected in fiscal year 1983

15. Number of continuous ground-water-level stations and sources of funding support, fiscal year 1983

16. Number of scheduled, long term operation groundwater-level stations and sources of funding support, fiscal year 1983

17. Number of short term or project ground-water-level stations and the sources of funding support, fiscal

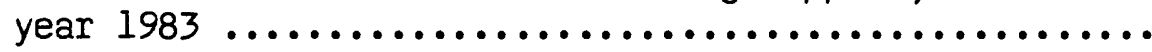

18. Number of stations, by State, at which ground-waterquality data were collected in fiscal year $1983 \ldots . .$. .

19. Number of scheduled, long term operation ground-waterquality stations and the sources of funding support,

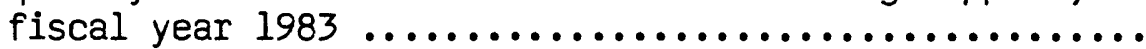

20. Number of short term or project ground-water-quality stations and the sources of funding support, fiscal

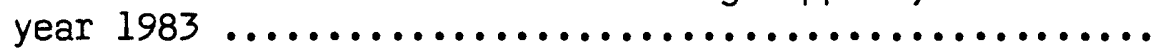

21. Number of stations, by State, at which precipitation data were collected in fiscal year 1983 ..............

22. Number of precipitation quantity stations and the source of funding support, fiscal year 1983 ...........

23. Number of precipitation quality stations and the source of funding support, fiscal year 1983

TABLES

Table 1. Types and number of hydrologic data collection stations operated by the U.S. Geological Survey during the 1983 fiscal year and the sources of funding support 
OPERATION OF HYDROLOGIC DATA COLLECTION STATIONS

BY THE U.S. GEOLOGICAL SURVEY IN 1983

By Alberto Condes de la Torre

ABSTRACT

The U.S. Geological Survey operated hydrologic data collection stations during 1983 in response to the needs of all levels of Government for hydrologic information. Surface-water discharge was determined at 11,076 stations; stage data on streams, reservoirs, and lakes were recorded at 2,136 stations; and surface-water quality was determined at 4,610 stations. Ground-water levels were measured at 35,621 stations, and the quality of ground water was determined at 7,648 stations nationwide. Information on precipitation quantity was collected at 800 stations, and quality of precipitation was analyzed at 121 stations. Funding support for the hydrologic stations was derived either solely or from a combination of three major sources--the Geological Survey's Federal Program, the FederalState Cooperative Program, and reimbursements from other Federal agencies. 


\section{INTRODUCTION}

The U.S. Geological Survey operates hydrologic data collection stations throughout the United States, Puerto Rico, and several Trust Territories. These hydrologic stations are used to monitor the quantity and quality of the water in the Nation's streams, lakes, and reservoirs, changes in ground-water levels, and the quality of the ground water. The activities are carried on in coordination with agencies at all governmental levels (Gilbert and Buchanan, 1982).

The purpose of this report is to describe the number and distribution of hydrologic data stations operated during the 1983 fiscal year. The report also identifies the number of hydrologic stations by sources of funding support--the Geological Survey's Federal program, the Federal-State Cooperative Program, and reimbursements from other Federal agencies--or from a combination of these.

\section{SURFACE WATER}

Surface-water discharge (flow) was determined by the U.S. Geological Survey at 11,076 stations in fiscal year 1983. At 7,152 of these stations, continuous discharge records were computed. That is, records were kept such that the flow can be determined for any moment during any day. At 3,924 other streamflow stations, partial records were collected. For example, at a station where there is an interest only in peak flows, data are collected and recorded only at stages greater than some predetermined level. The number of stations in each State where continuous surface-water discharge data were collected ranged from 690 in California to 12 in Delaware (figure 1). The Federal-State Cooperative Program funded operation of the largest number of continuous streamflow discharge stations--it provides sole support for 3,567 stations, and in combination with other sources, provided support for 1,258 more (figure 2). The Federal-State Cooperative Program also funded the largest number of partial record discharge stations--sole support of 2,860 stations, and in combination with other sources, 586 more (figure 3).

At all stations where discharge was computed, a record of the stage--water surface elevation--was maintained either continuously or during certain events at partial record stations. In addition, stage only was collected by the Geological Survey at 890 stream stations. At 419 of these stream stations, stage was collected continuously. The continuous collection of stage only at streams ranged from 124 stations in Florida to none in several States (figure 4). The reimbursement from other Federal agencies (OFA) supported the largest number of continuous stage only stations--193 (figure 5)--while the Federal-State Cooperative Program supported the most partial record stage only stations--374 (figure 6). 
Stage data were also collected at 1,246 stations on lakes and reservoirs by the Geological Survey. Continuous record of stage was collected at 846 lake and reservoir stations, ranging from 115 in Texas to none in several States (figure 7). The Federal-State Cooperative Program supported the largest number of both continuous (figure 8 ) and partial record (figure 9) stage stations on lakes and reservoirs--467 and 283 stations, respectively.

Stream samples were collected and analyzed for water-quality characteristics at 4,610 stations nationwide (figure 10). The types of waterquality parameters measured varies from site to site and could include: field determinations for temperature, specific conductance, $\mathrm{pH}$, dissolved oxygen, fecal coliform, and fecal streptococci; common constituents such as calcium, magnesium, fluoride, sodium, potassium, dissolved solids, silica, chloride, sulfate, hardness, bicarbonate, carbonate, and turbidity; major nutrients such as phosphorus, ammonia, nitrate, and nitrite; trace metals such as arsenic, cadmium, chromium, cobalt, copper, iron, lead, manganese, mercury, selenium, and zinc; and selected radiochemical parameters and suspended sediment. A continuous record was maintained at 784 of these sites (figure 11), mainly for water temperature and conductance, but other parameters such as dissolved oxygen and $\mathrm{pH}$ are also recorded continuously at times. There are 2,906 stream sites at which water-quality data were collected as part of a scheduled, long term operation (figure 12). These include 501 stations, supported in the Federal Program, which make up the National Stream Quality Accounting Network (NASQAN). NASQAN was established by the U.S. Geological Survey to provide a uniform basis for continually assessing the quality of United States streams. An identical suite of water-quality characteristics is measured at each NASQAN station using the same set of rules concerning sample collection techniques, frequency of sampling, and analytical methods (Briggs and Ficke, 1977). There are 920 stations which were sampled as short term or project stations (figure 13). The collection of surface-water-quality data received its largest funding support from the Federal-State Cooperative Program.

\section{GROUND WATER}

Estimates indicate that 88 billion gallons per day of ground water are withdrawn in the United States for public supply, rural use, irrigation, and industrial uses (Solley and others, 1983). To provide the information required to develop knowledge about ground water, a good data base must be established and maintained. Water-level fluctuations are indicators of the stresses placed on aquifers, their ability to yield water, and the quantity of water in storage beneath the earth's surface. The U.S. Geological Survey collected information on ground-water levels at 35,621 sites in 1983 (figure 14). Data on water levels were collected continuously at 1,982 sites, of which 1,313 were funded by the Federal-State Cooperative Program (figure 15). 
To assess long term trends, ground-water levels were collected at 24,047 stations as part of a scheduled, long term operation (figure 16). When special areal studies were conducted, water levels were at times collected at short term or project stations to supplement the information available in the area from the long term stations. In 1983, water-level data were collected at 9,592 stations for these projects (figure 17). The Federal-State Cooperative Program provided funding support for 64 percent of these stations.

The quality of ground water is also of importance to users. In 1983, ground water was sampled and analyzed at 7,648 stations (figure 18). To maintain information on the changes in quality of critical ground-water bodies, samples were collected at 3,071 stations as part of a scheduled, long term operation (figure 19). Of these, sampling at 2,251 stations was funded by the Federal-State Cooperative Program. Ground-water-quality data were also collected at 4,577 stations to provide information needed for short term, generally site-specific studies (figure 20 ).

\section{PRECIPITATION}

Collection of precipitation data by the U.S. Geological Survey is undertaken only as part of an investigation of a specific hydrologic system. Most of the time, precipitation data from the National Weather Service is used. Precipitation data were collected at 800 sites nationwide (figure 21). At 121 of these sites, quality of precipitation was determined. The largest support for the collection of precipitation quantity (figure 22) and quality (figure 23) data came from the Federal-State Cooperative Program and the Federal Program, respectively.

\section{SUMMARY}

The U.S. Geological Survey operates an extensive network nationwide for the collection of hydrologic data, which is summarized in table 1. The surface-water data include information on discharge and stage of streams, stage of lakes and reservoirs, and surface-water quality. Data are also collected on ground-water levels and the quality of ground water. Data on the quantity and quality of precipitation are usually collected only in selected study areas. 


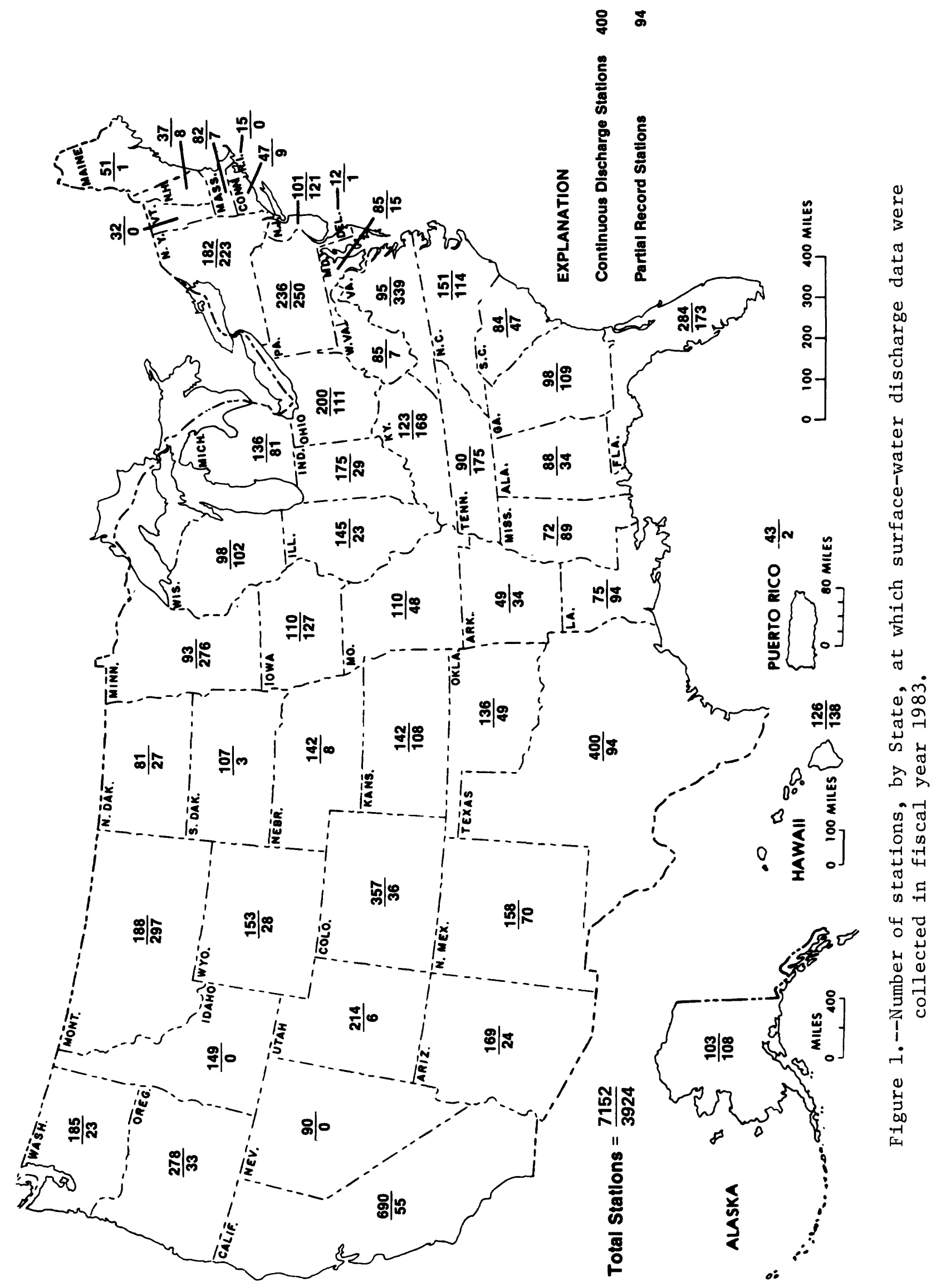




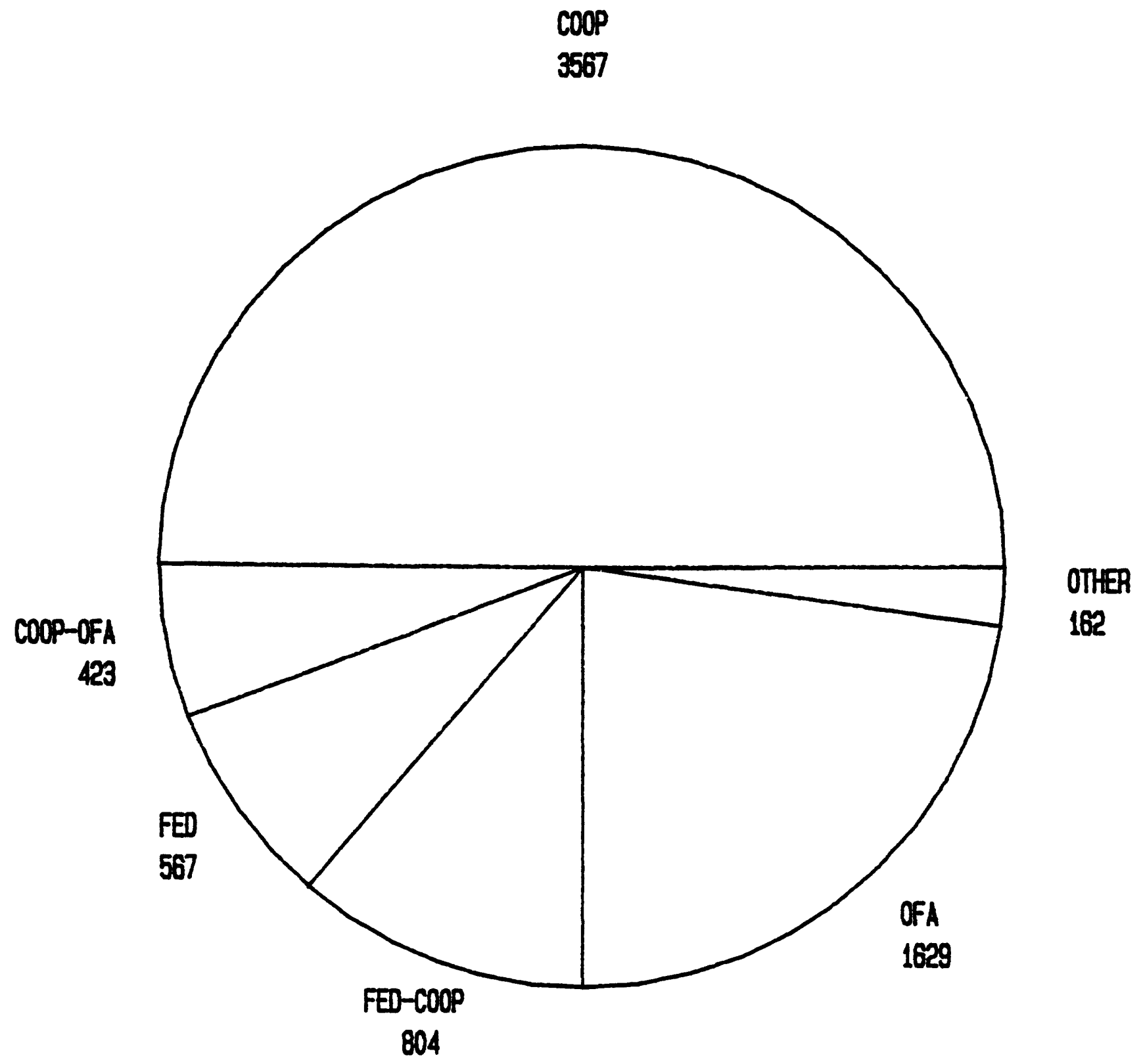

Total Stations $=7,152$

EXPLANATION:

\section{SINGLE PROGRAM SUPPORT}

FED $=$ Federa

OFA $=$ Other Federal Agencies

COOP = Federal-State Cooperative Program

CONBINED PROGRAN SUPPORT

FED-COOP = Federal and Federal-State Cooperative Program

COOP-OFA=Federal-State Cooperative and Other Federal Agencies

Figure 2.--Number of continuous surface-water discharge stations and sources of funding support, fiscal year 1983. 


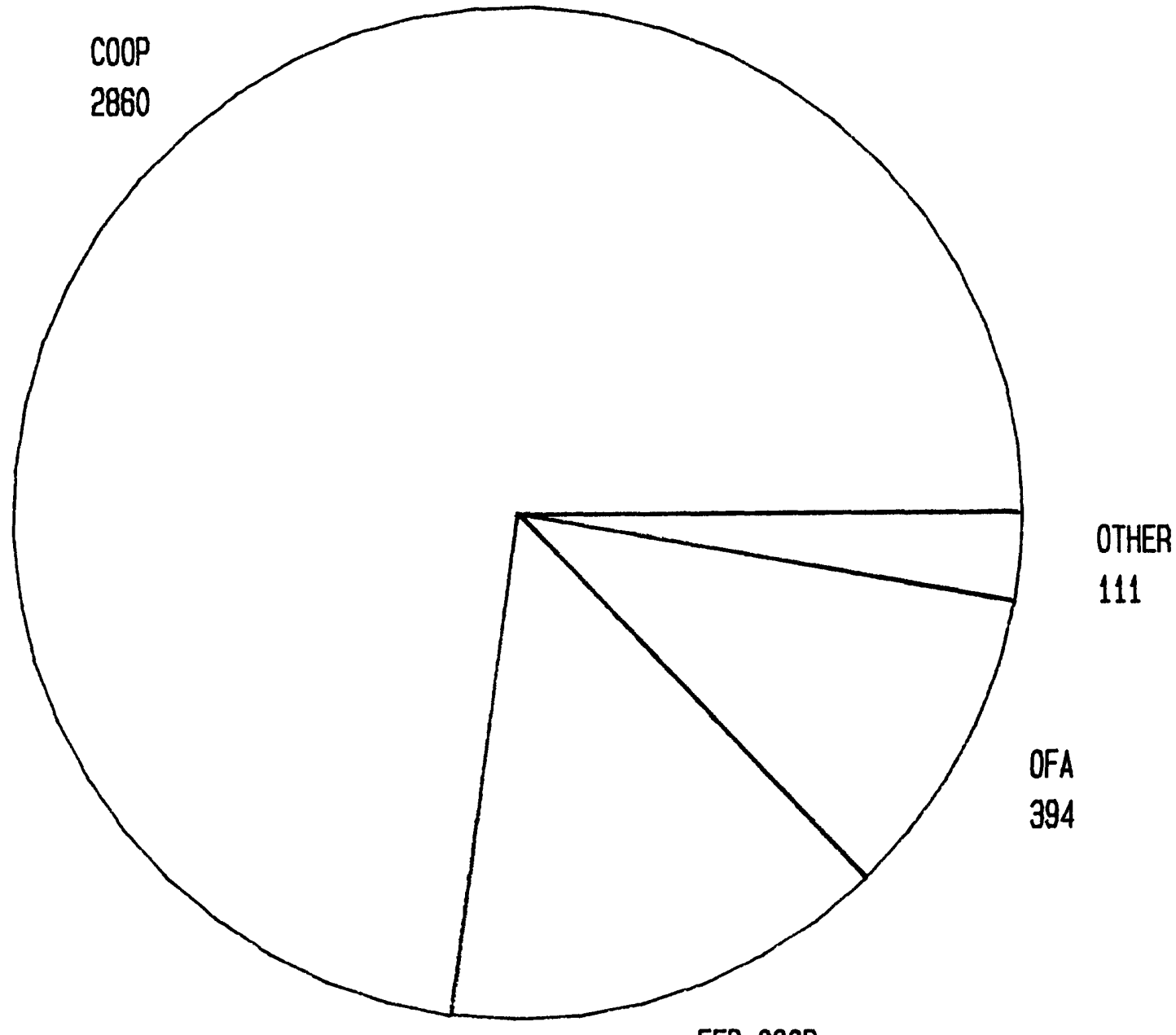

FED-COOP

559

Total Stations $=3,924$

\section{EXPLANATION:}

SINGLE PROGRAM SUPPORT

OFA $=$ Other Federal Agencies

COOP = Federal-State Cooperative Program

COMBINED PROGRAM SUPPORT

FED-COOP = Federal and Federal-State Cooperative Program

Figure 3.--Number of partial record surface-water discharge stations and sources of funding support, fiscal year 1983 . 


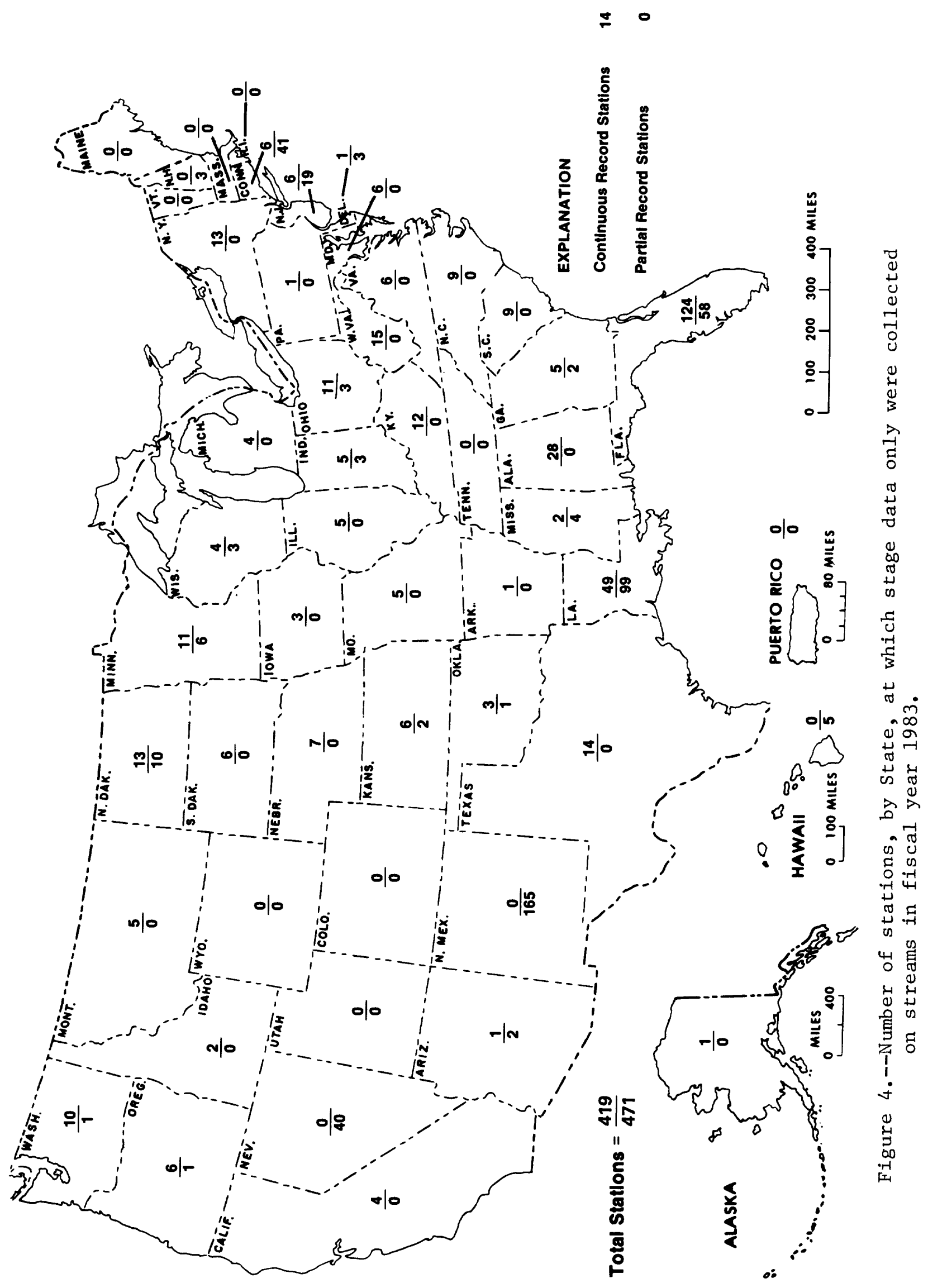




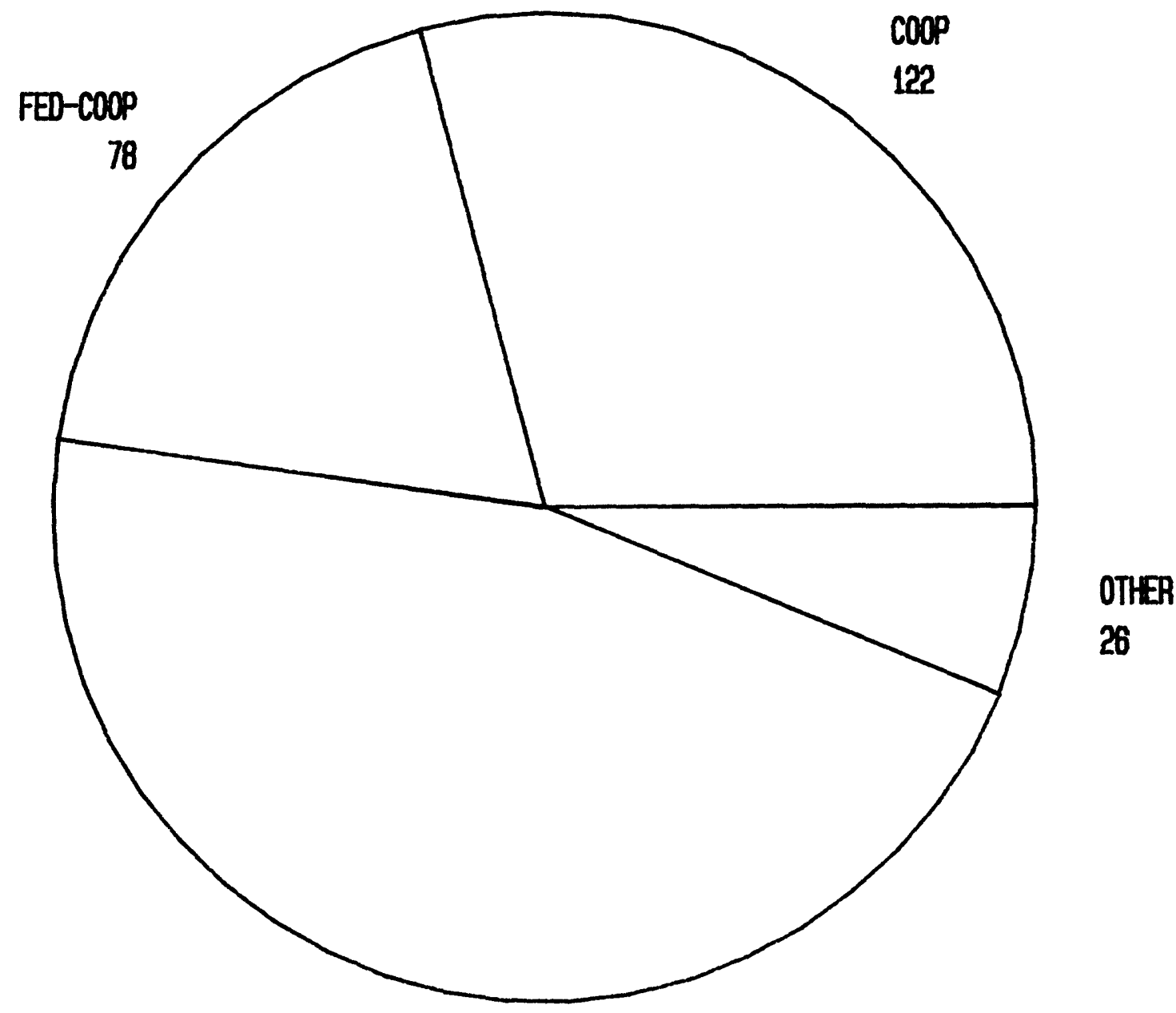

OFA

193

Total Stations $=\mathbf{4 1 9}$

\section{EXPLANATION:}

SINGLE PROGRAN SUPPORT

OFA $=$ Other Federal Agencies

COOP $=$ FederaI-State Cooperative Program

COABINED PROGRAM SUPPORT

FED-COOP = Federal and FederaI-State Cooperative Program

Figure 5.--Number of continuous surface-water staje only statiuis on streams anú suurces of funding support, fiscal year 1983. 


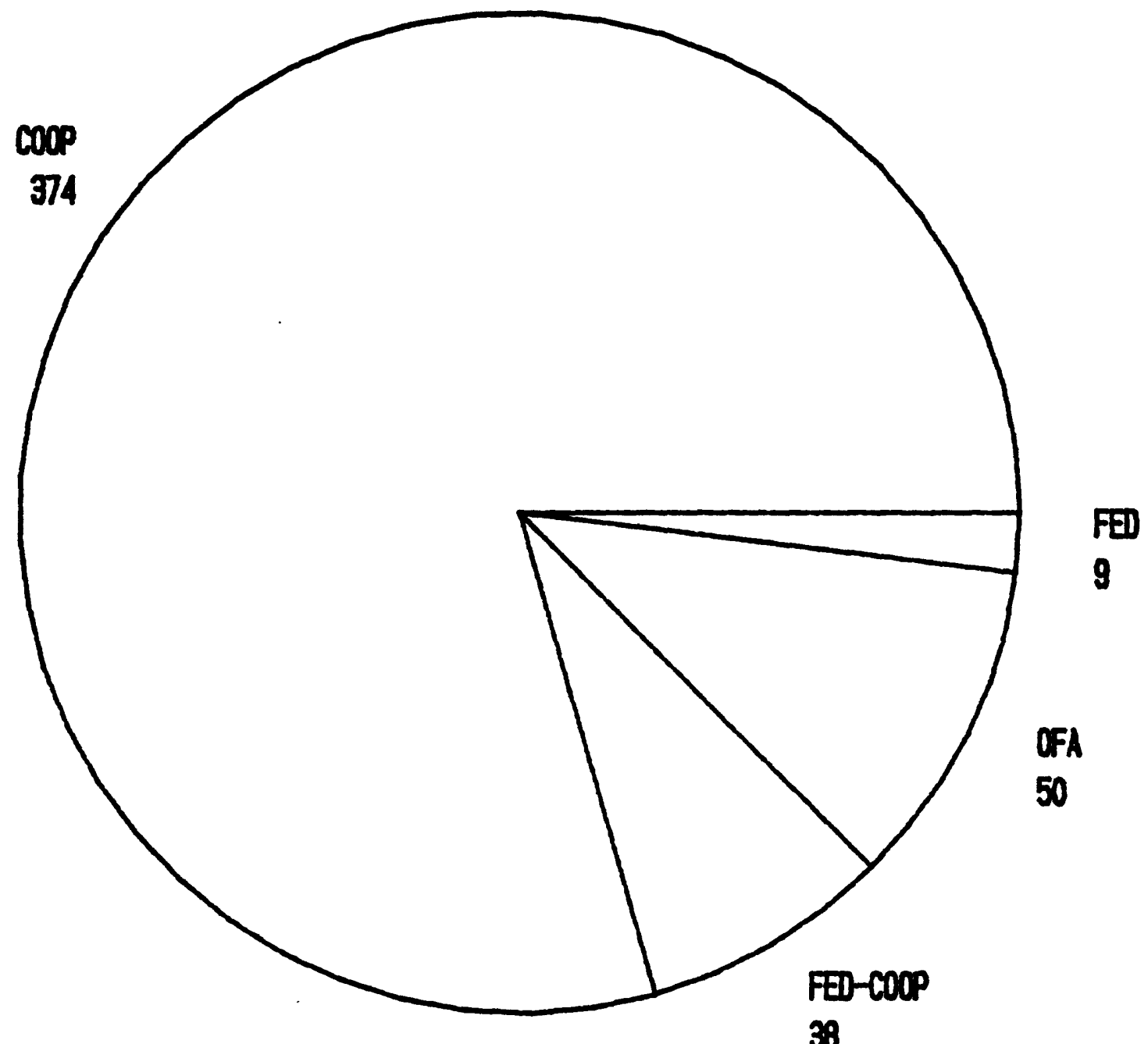

Total Stations $=\mathbf{4 7 1}$

\section{EXPLANTIOK}

\section{STNELE PPOCFUN SUPPORT}

FED = Federal

OFA $=$ Other Federal Agencies

coop = Federal-State cooperative Progran

COYAINED PROCRAM SUPPORT

FED-COOP = Federal and Federal-State Cooperative Progran

Figure 6.--Number of partial record surface-water stage only stations on streams and the sources of funding support, fiscal year 1983 . 


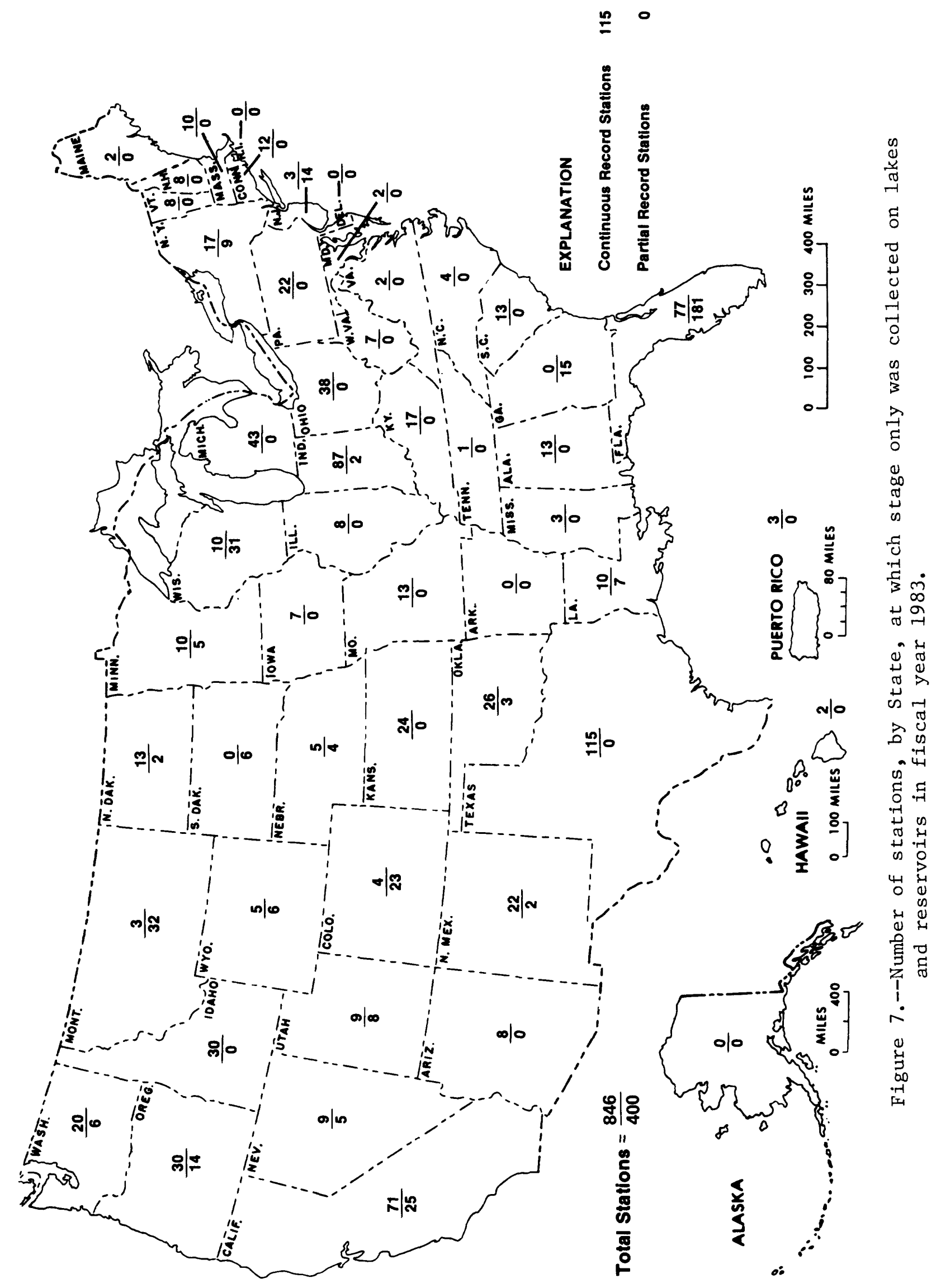




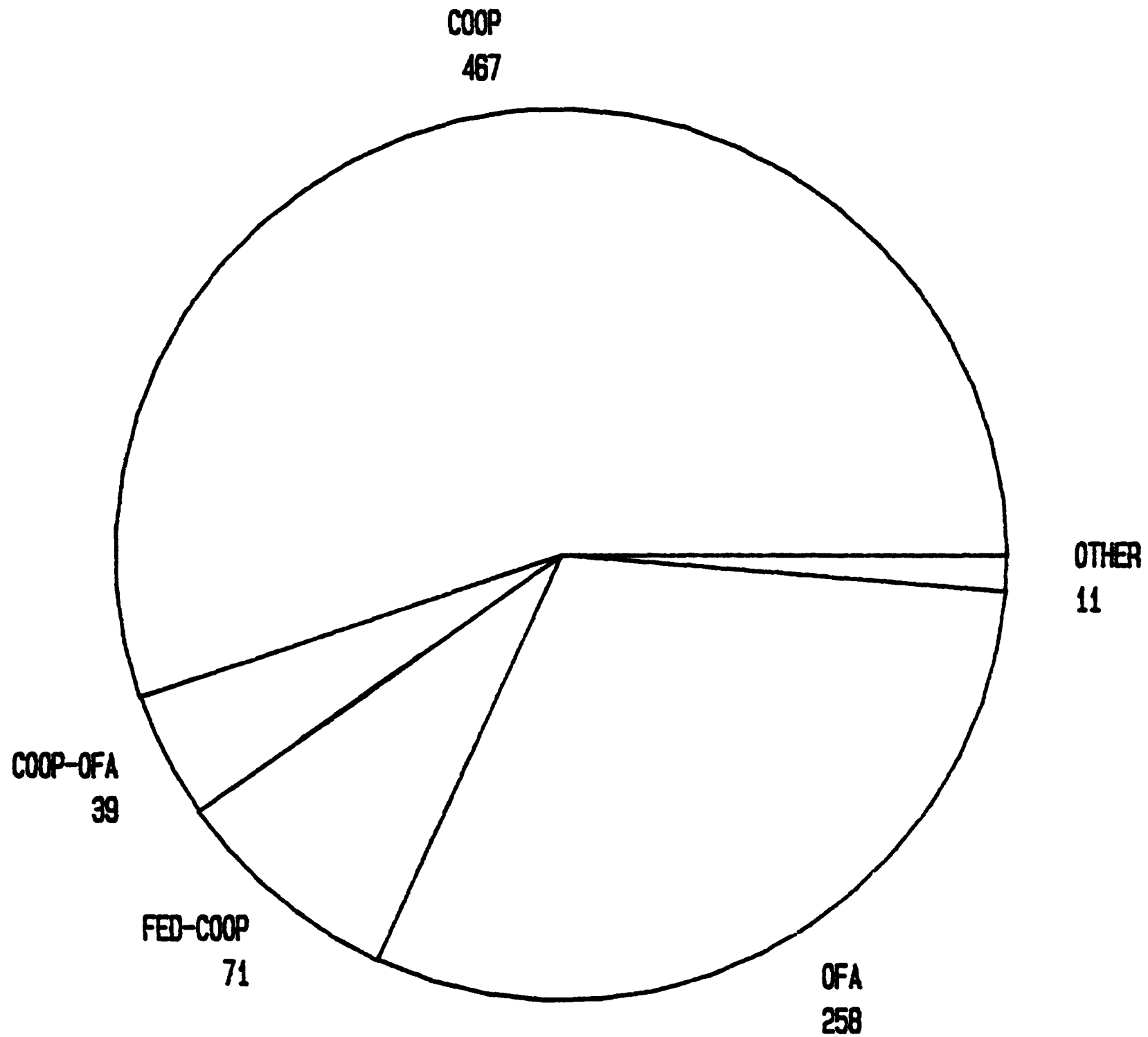

Total Stations $=846$

\section{EXPLANATTONE}

\section{SINGLE PROGRAM SUPPORT}

OFA $=$ Other Federal Agencies

COOP = Federal-State Cooperative Program

CONBINED PROGRAM SUPPORT

FED-CDOP = Federal and FederaI-State Cooperative Program

COOP-OFA=Federal-State Cooperative and Other Fed Agencies

Figure 8.--Number of continuous surface-water stage only stations on lakes and reservoirs and the sources of funding support, fiscal year 1983 . 


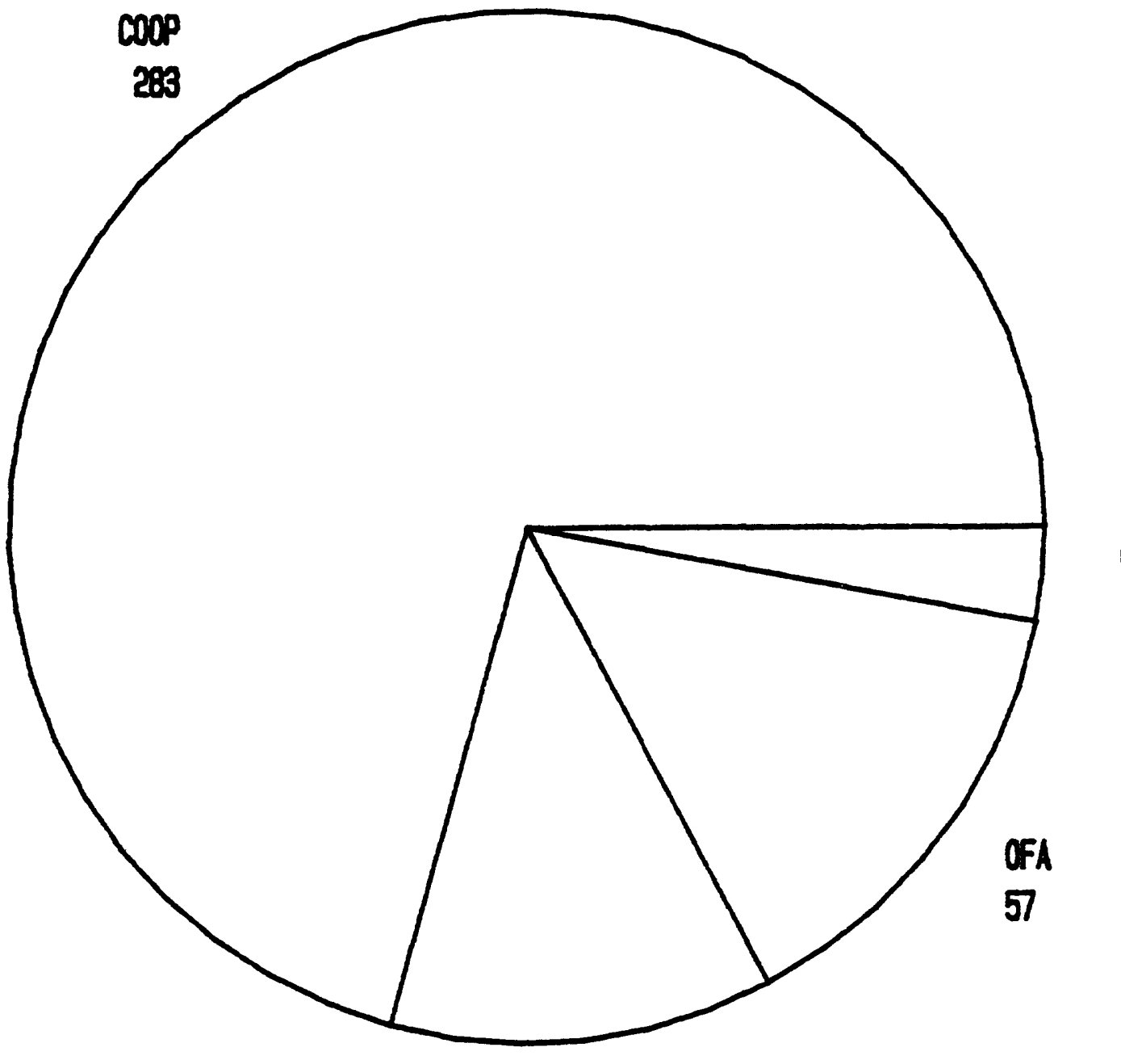

OTHER

12

FED-COOP

48

Total Stations $=400$

\section{EXPLANATTOK}

STNGE PROERAY SUPPORT

FED $=$ Federal

OFA $=$ Other FederaI Agencies

Coop = Federal-State Cooperative Progran

COMBINED PROGRAY SUPPORT

FEDD-COOP $=$ Federal and Federal-State Cooperative Program

Figure 9.--Number of partial record surface-water stage only stations on lakes and reservoirs and the sources of funding support, fiscal year 1983. 


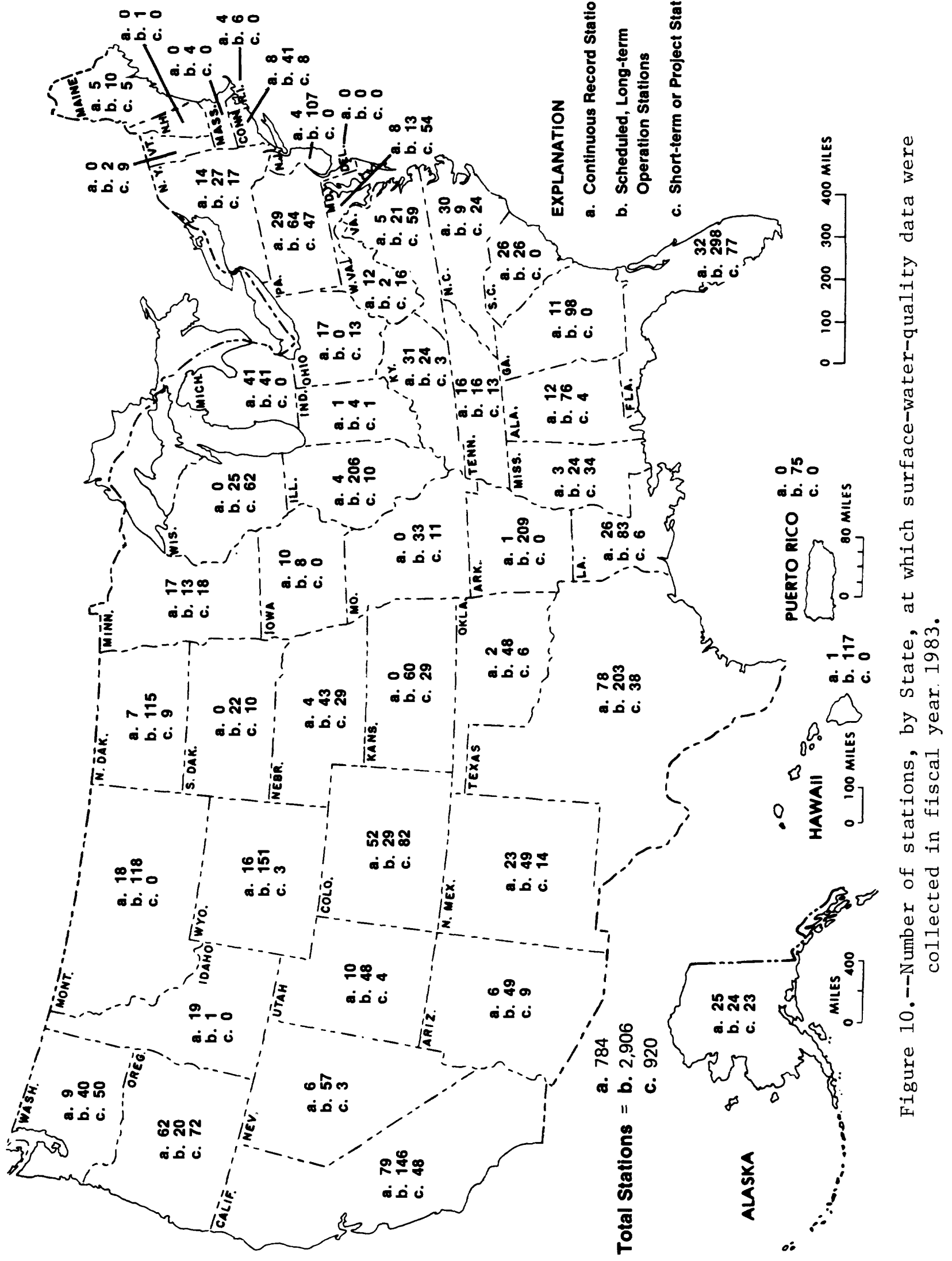




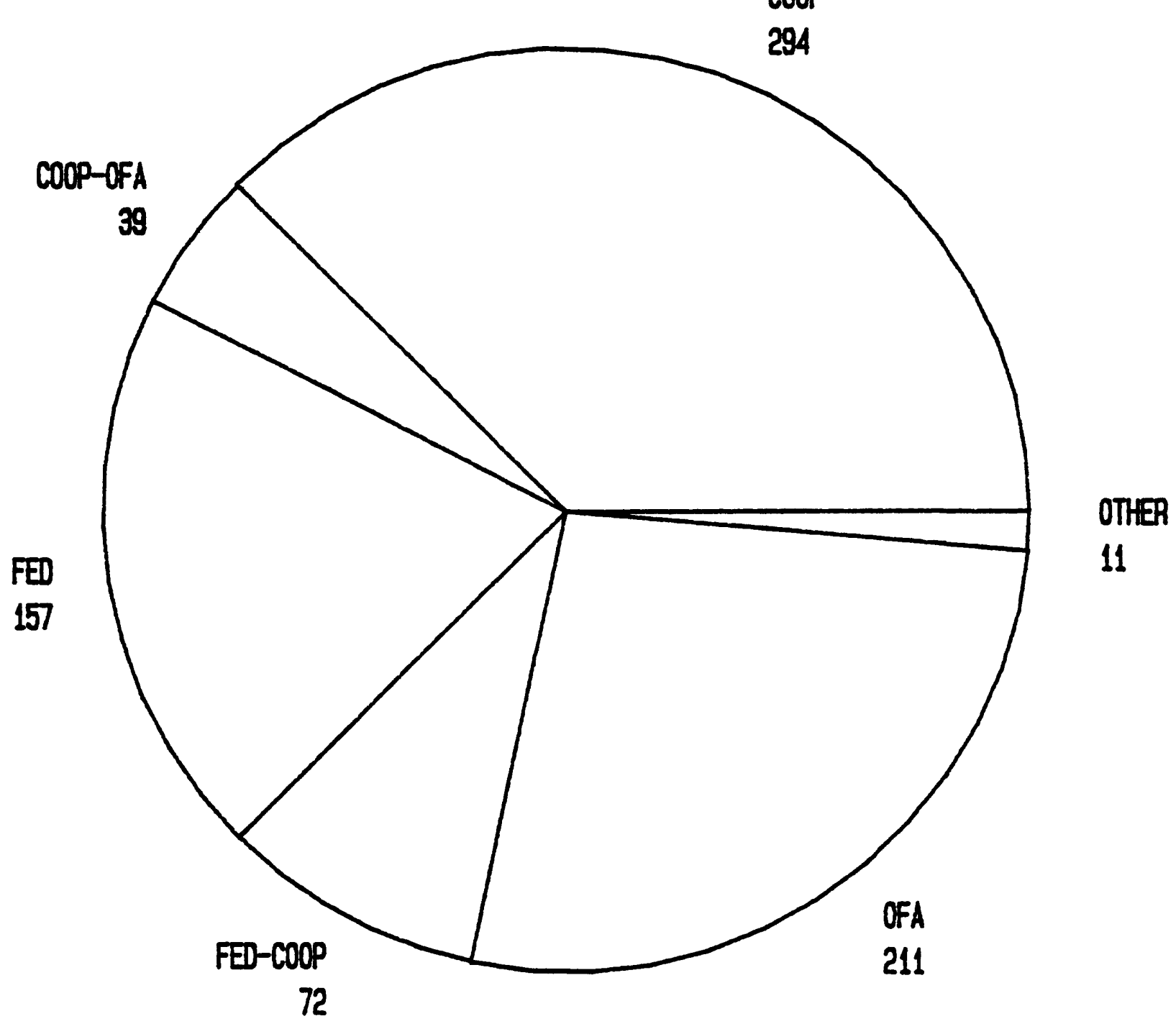

Total Stations $=784$

\section{EXPLANATIOK:}

\section{SINGLE PROERAM SUPPORT}

FED $=$ Federal

OFA $=$ Other Federal Agencies

COOP = Federal-State Cooperative Progran

CONBINED PROGRAM SUPPORT

FED-COOP = Federal and Federal-State Cooperative Progran

COOP-OFA=Federal-State Cooperative and Other Federal Agencies

Figure 11.--Number of continuous surface-water-quality stations and sources of funding support, fiscal year 1983. 


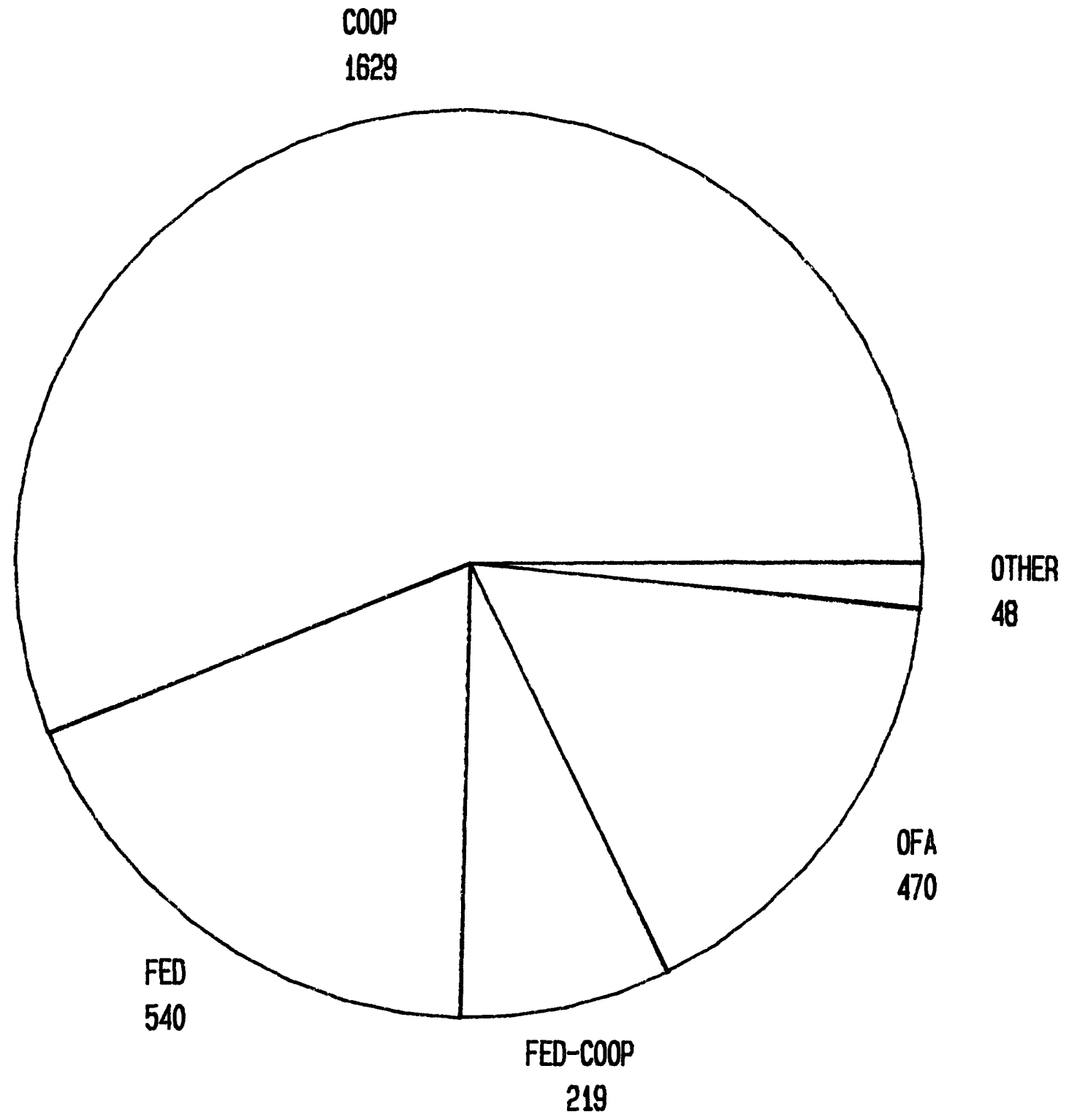

Total Stations $=2,906$

EXPLANATION:

SINGLE PROGRAM SUPPORT

FED $=$ Federal

OFA $=$ Other Federal Agencies

COOP $=$ Federal-State Cooperative Program

COMBINED PROGRAM SUPPORT

FED-COOP = Federal and Federal-State Cooperative Progran

Figure 12.--Number of scheduled, long term operation surface-wator quality stations and sources of funding support, fiscal year 1983 . 


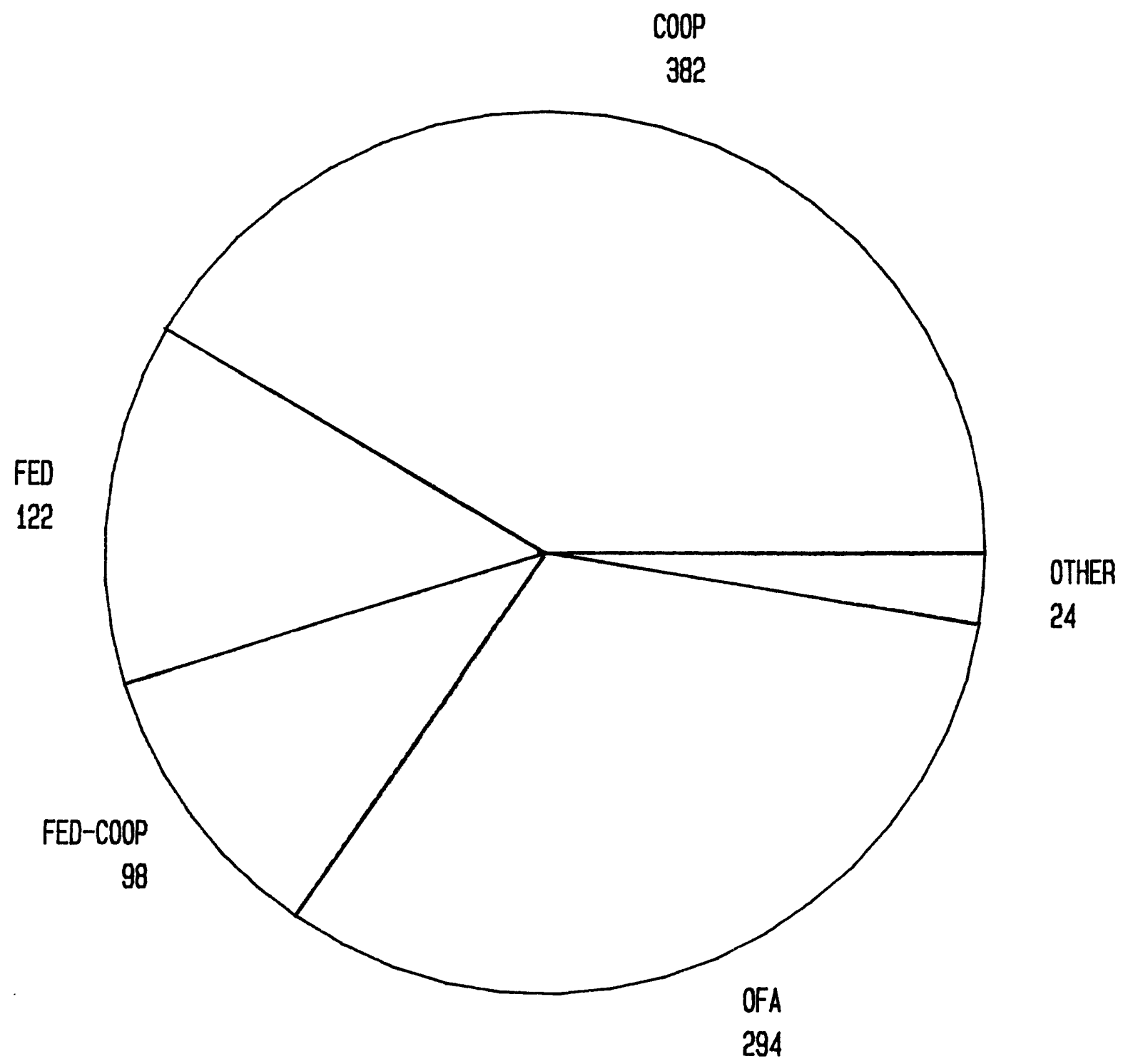

Total Stations $=920$

\section{EXPLANATION:}

SINGLE PROGRAM SUPPORT

FED $=$ FederaI

OFA $=$ Other Federal Agencies

COOP = Federal-State Cooperative Program

CONBINED PROGRAM SUPPORT

FED-COOP = FederaI and FederaI-State Cooperative Program

\footnotetext{
Figure 13.--Number of short term or project surface-water-quality stations and sources of funding support, fiscal year 1983 .
} 


$$
\text { + }
$$

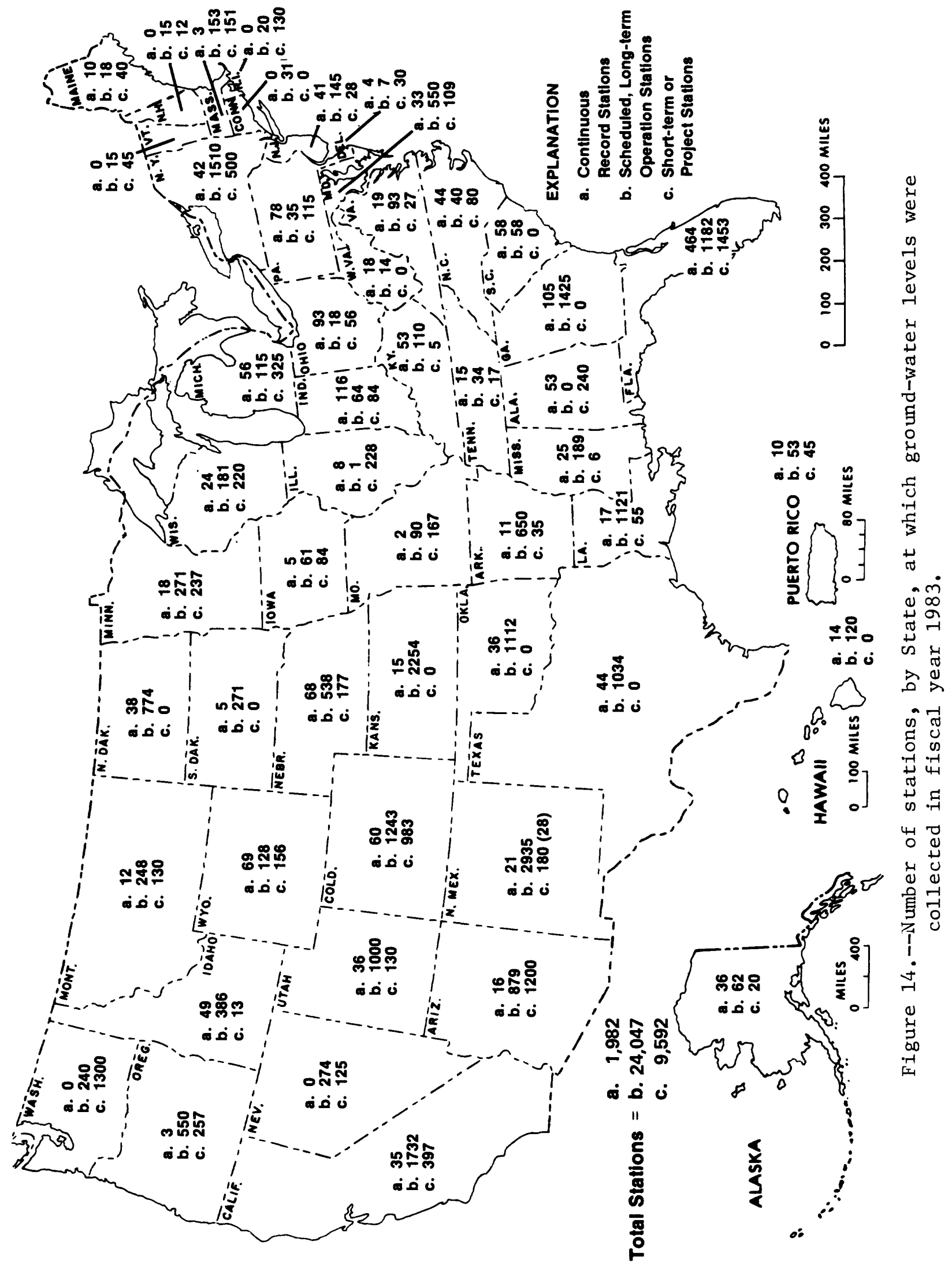




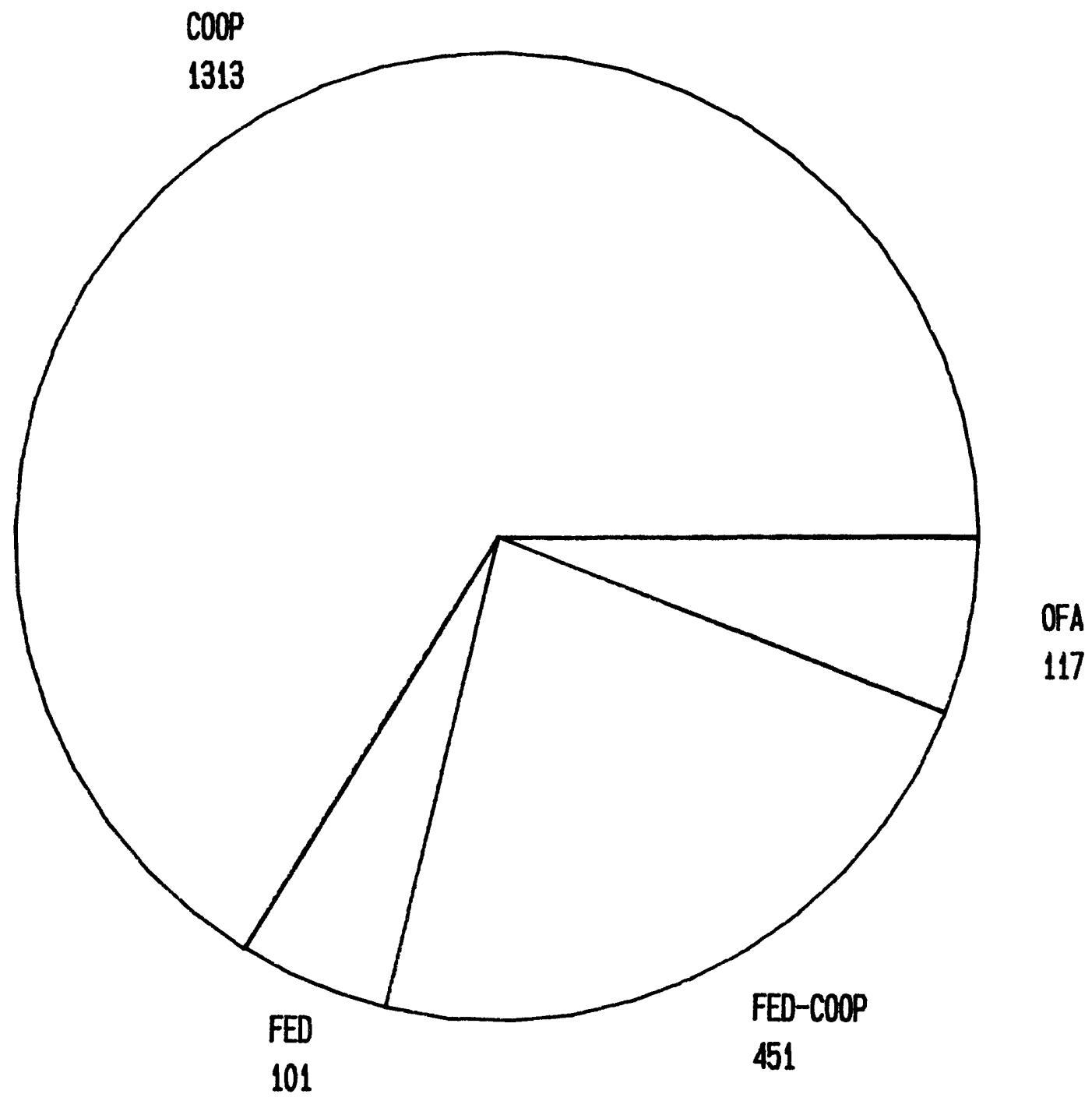

Total Stations $=1,982$

\section{EXPLANATION:}

\section{SINGLE PROGRAM SLPPORT}

FED $=$ Federal

OFA $=$ Other Federal Agencies

COOP = Federal-State Cooperative Progran

COMBINED PROGRAN SUPPORT

FED-COOP = Federal and Federal-State Cooperative Program

Figure 15.--Number of continuous ground-water level stations and sources of funding support, fiscal year 1983 . 


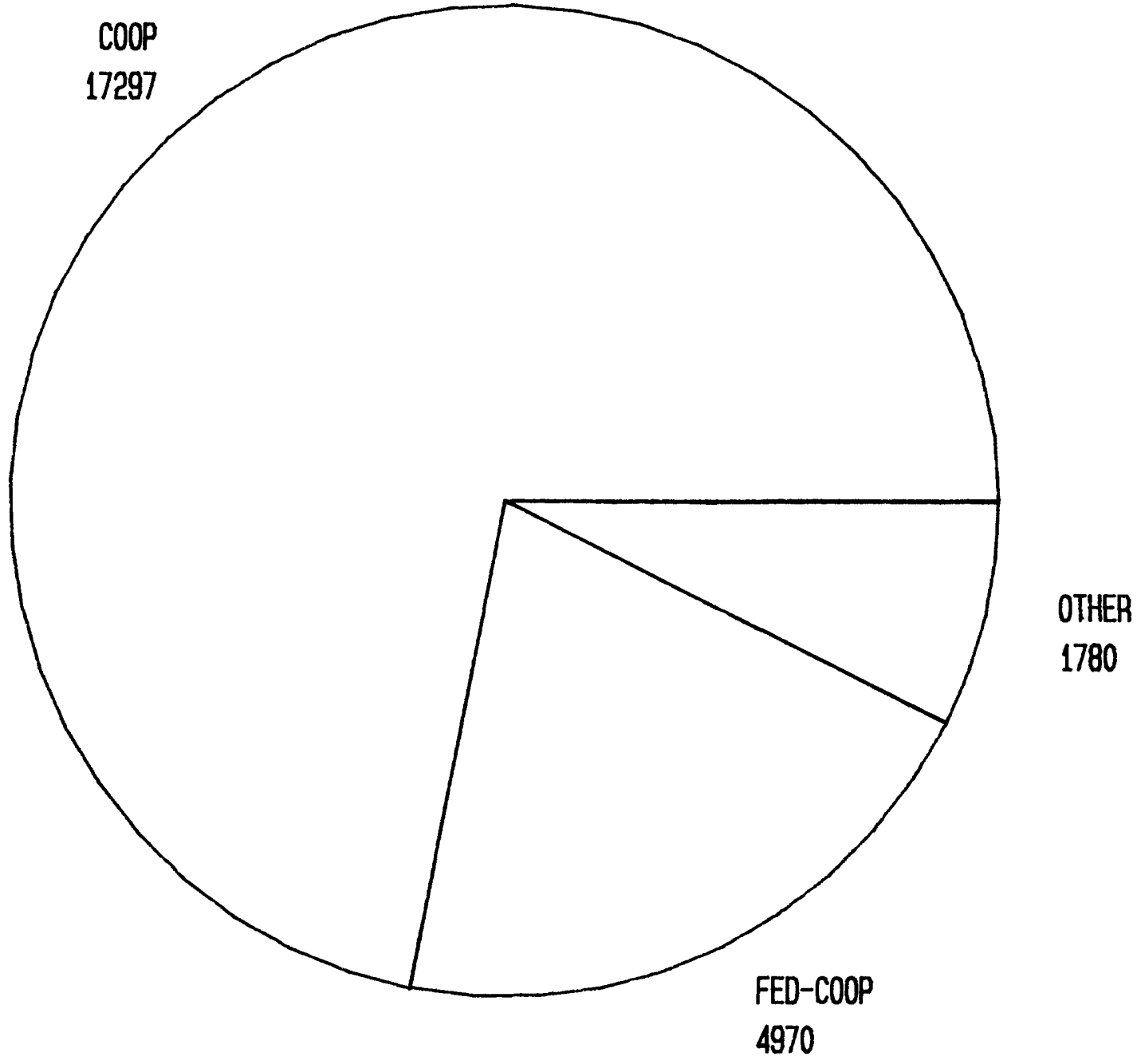

Total Stations $=24,047$

EXPLANATION:

SINGLE PROGRAM SUPPORT

COOP = Federal-State Cooperative Program

CONBINED PROGRAM SUPPORT

FED-COOP = Federal and Federal-State Cooperative Program

Figure 16.--Number of scheduled, long term operation ground-water level stations and sources of funding support, fiscal year 1983 . 


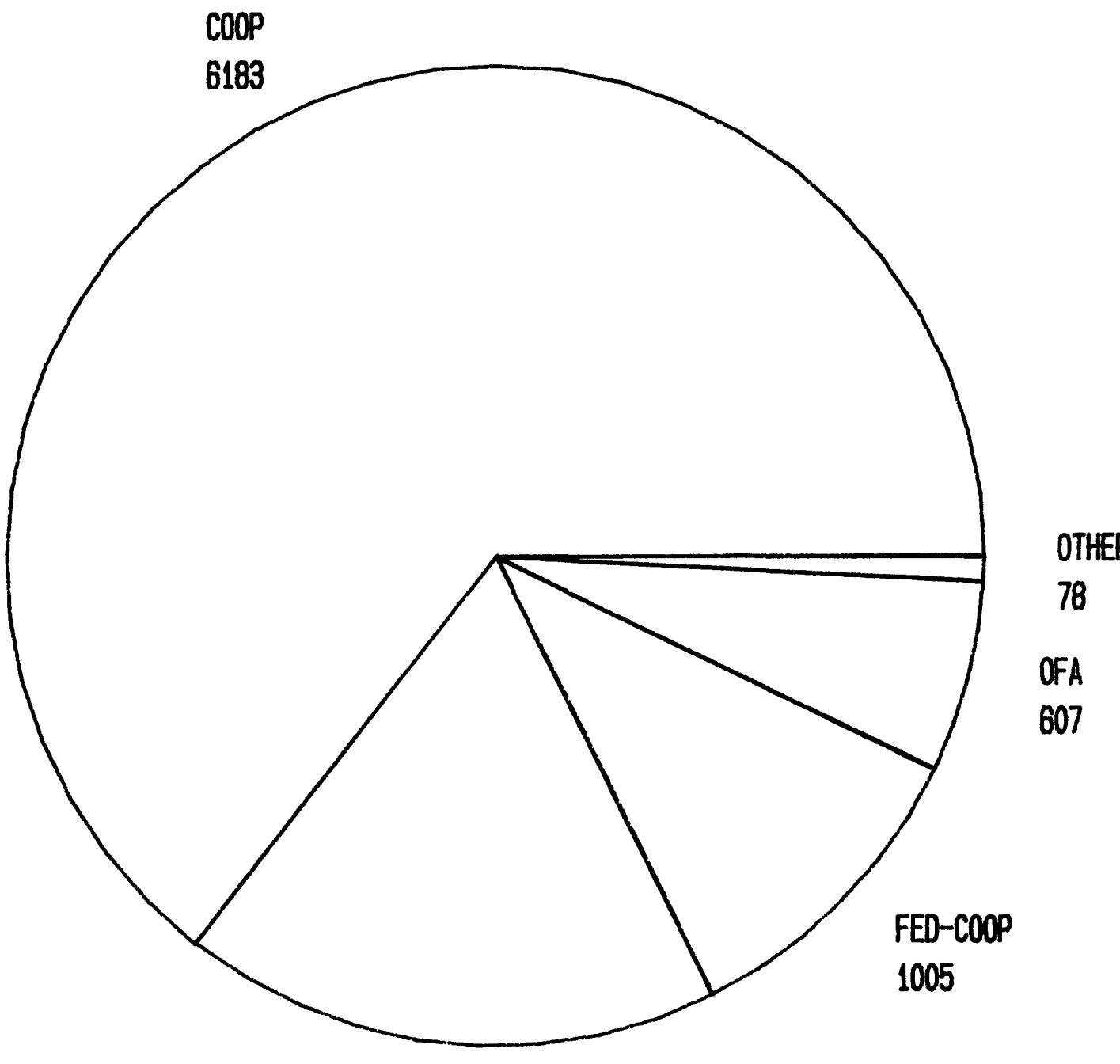

FED

1719

Total Stations $=9,592$

\section{EXPLANATION:}

STNGLE PROGRAM SUPPORT

FED $=$ Federal

OFA $=$ Other Federal Agencies

COOP = Federal-State Cooperative Program

COMBINED PROGRAM SUPPORT

FED-COOP = Federal and Federal-State Cooperative Progran

Figure 17.--Number of short term or project ground-water level stations and the sources of funding support, fiscal year 1983 . 


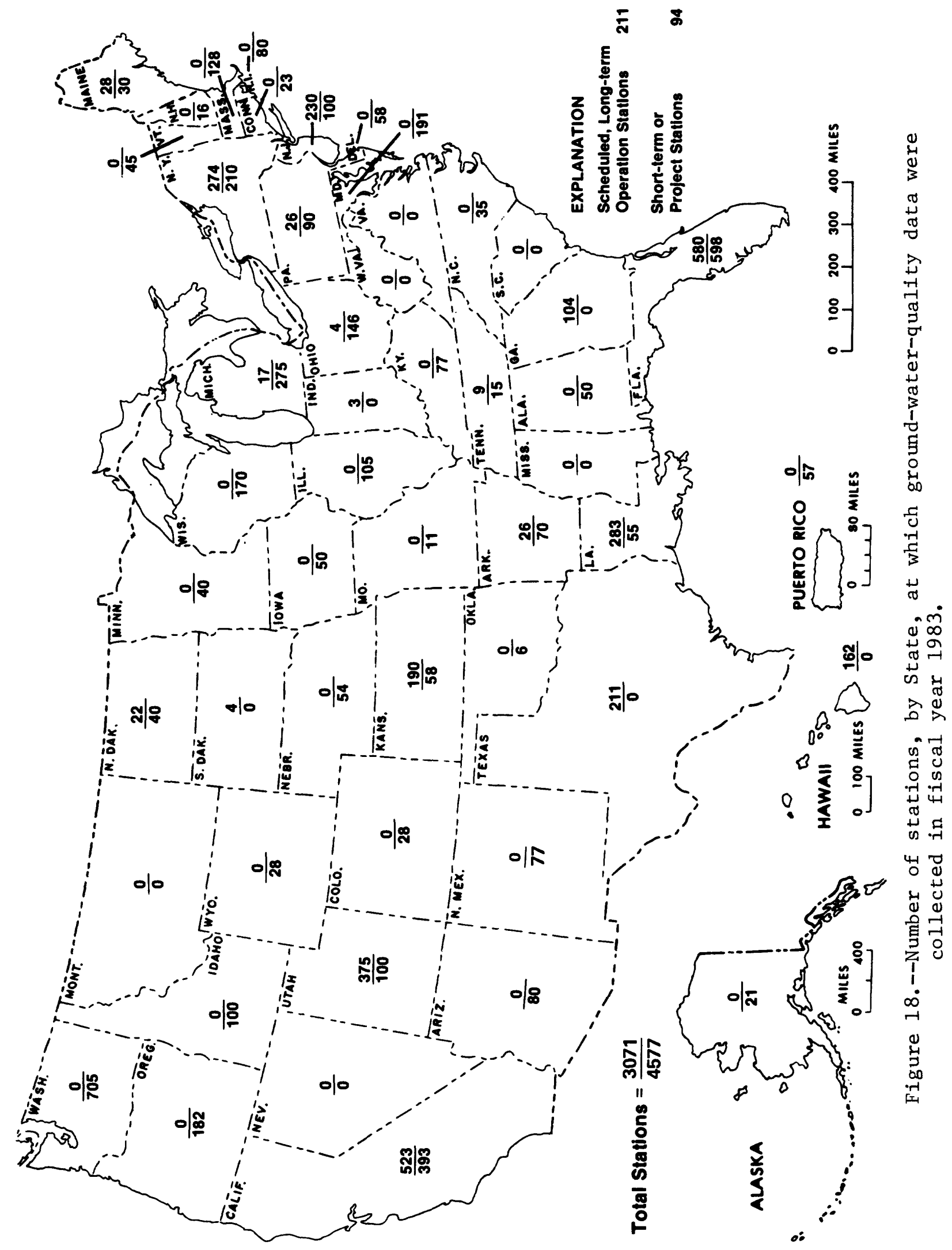




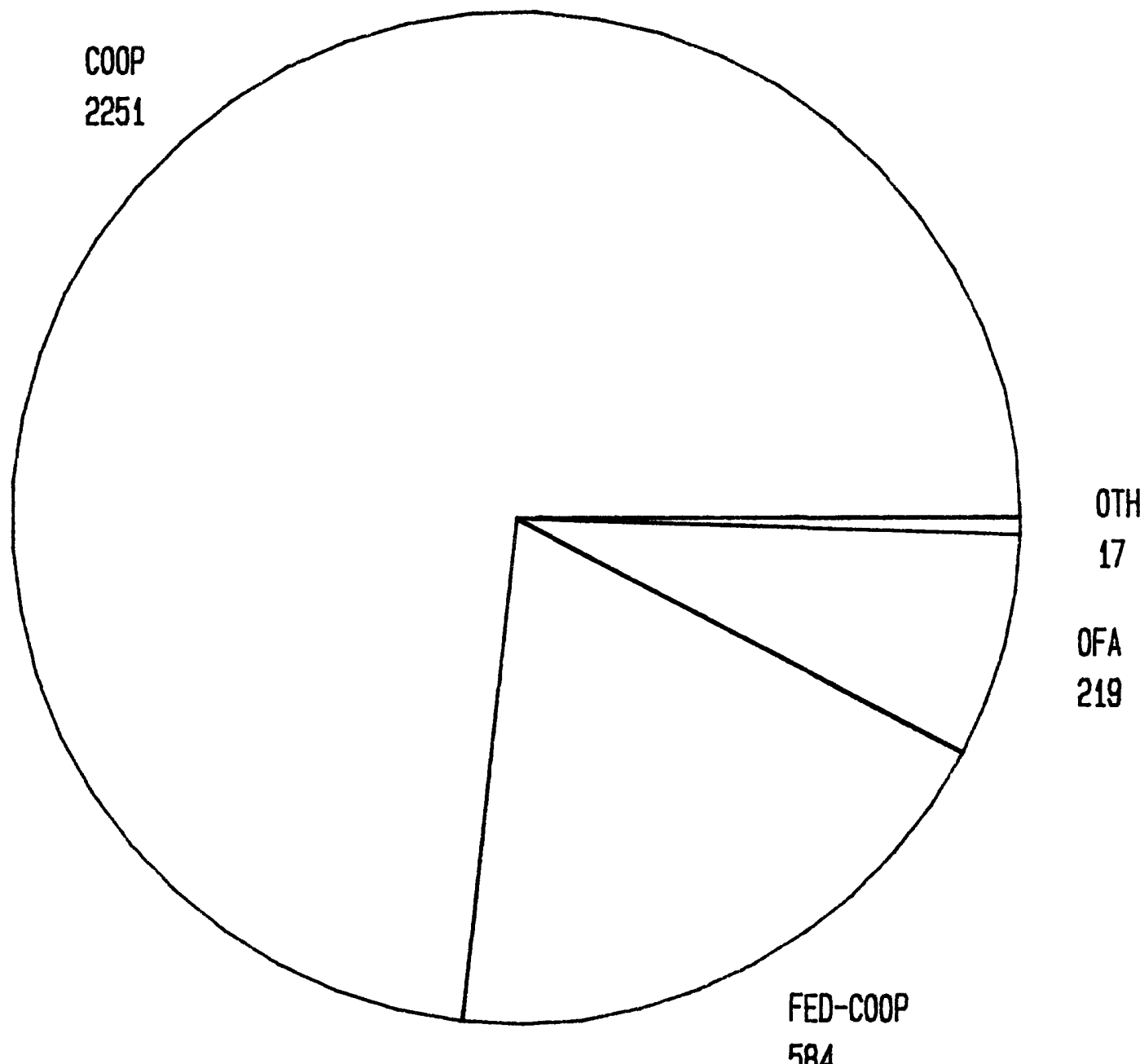

Total Stations $=3,071$

EXPLANATION:

SINGLE PROGRAM SUPPORT

OFA $=$ Other Federal Agencies

COOP = Federal-State Cooperative Program

COMBINED PROGRAM SUPPORT

FED-COOP = Federal and Federal-State Cooperative Program

Figure 19.--Number of scheduled, long term operation ground-water quality stations and the sources of funding support, fiscal year 1983 . 


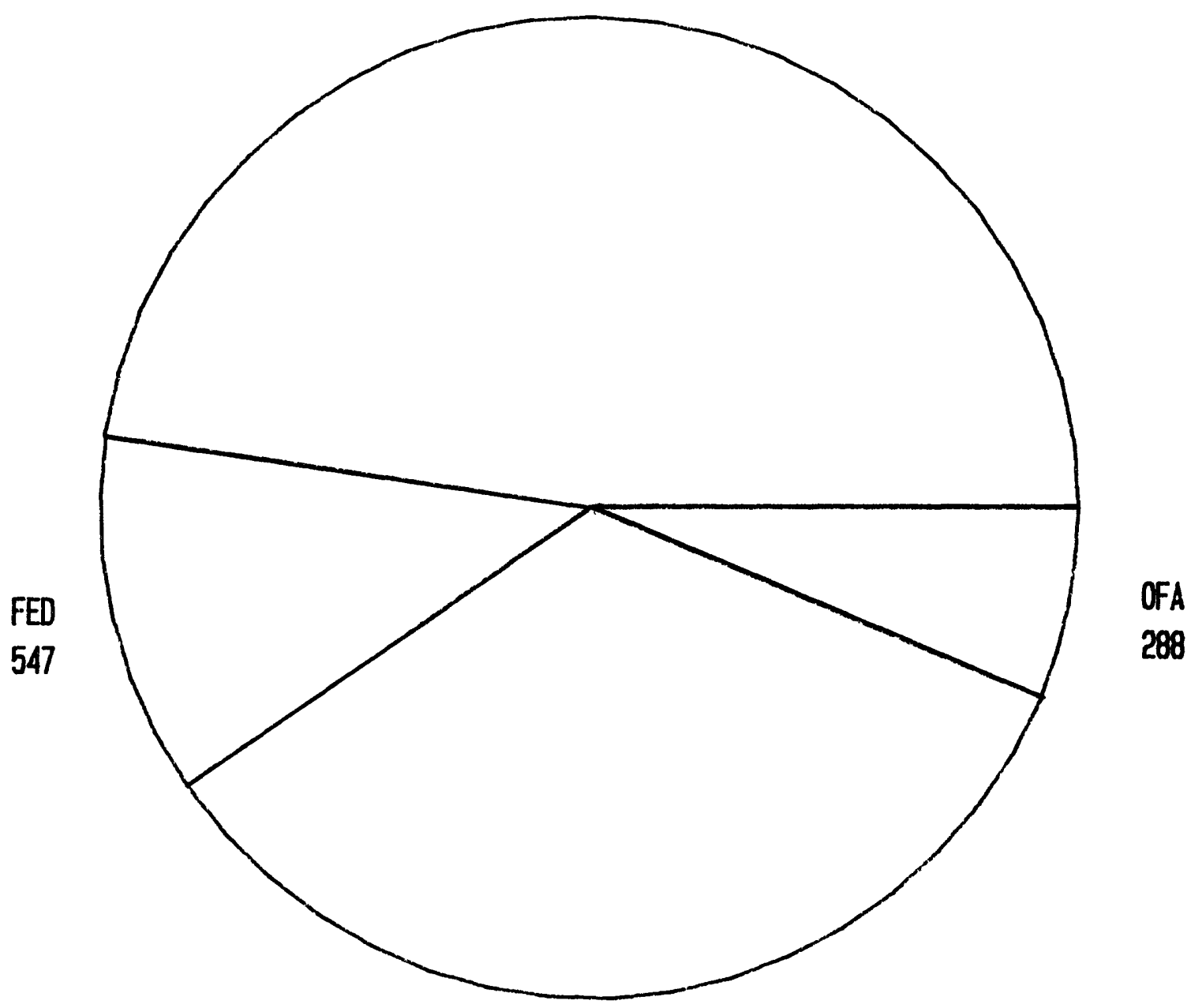

FED-COOP

1560

Total Stations $=4,577$

\section{EXPLANATION:}

\section{SINGLE PROGRAN SUPPORT}

FED $=$ FederaI

OFA $=$ Other Federal Agencies

COOP $=$ FederaI-State Cooperative Progran

\section{CONBINED PROGRAM SUPPORT}

FED-COOP = Federal and FederaI-State Cooperative Program

Figure 20.--Number of short term or project ground-water-quality stations and the sources of funding support, fiscal year 1983 . 


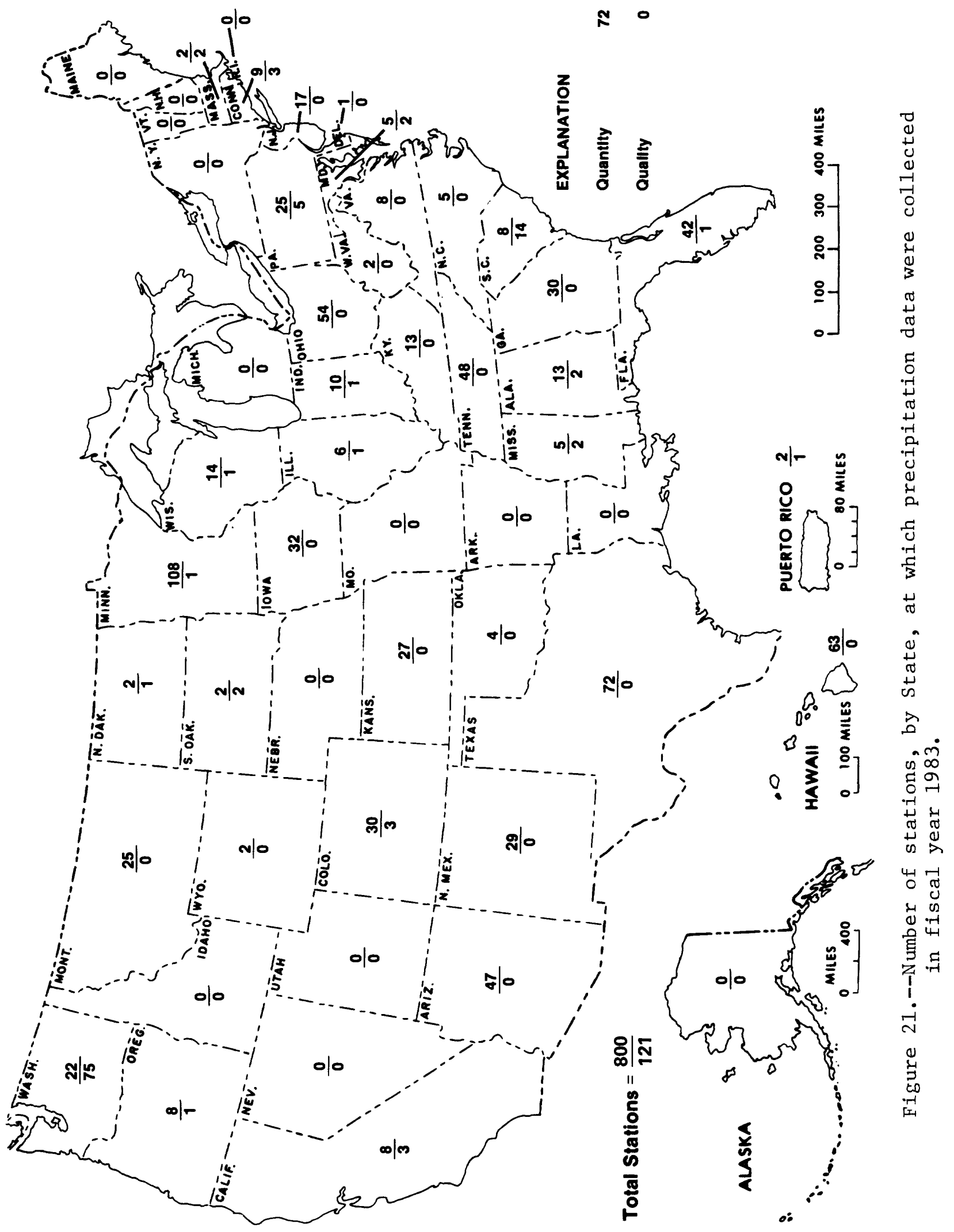




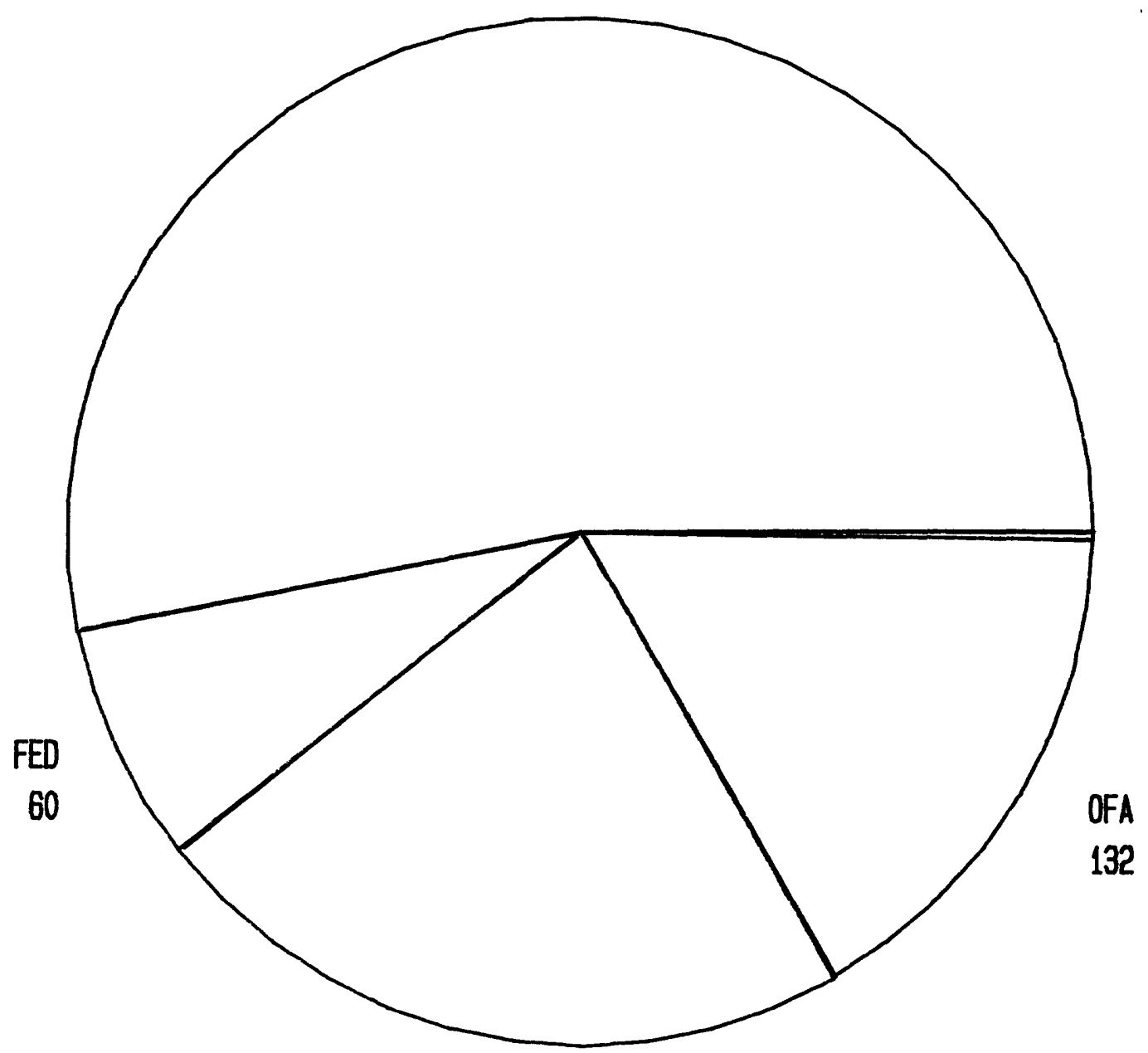

FED-OFA

FED-COOP

181

Total Stations $=800$

\section{EXPLANATION:}

SINGLE PROGRAM SUPPORT

FED $=$ Federal

OFA $=$ Other Federal Agencies

COOP = Federal-State Cooperative Program

COMBINED PROGRAM SUPPORT

FED-OFA = Federal and Other Federal Agencies

FED-COOP = Federal and Federal-State Cooperative Program

Figure 22.--Number of precipitation quantity stations and the source of funding support, fiscal year 1983 . 


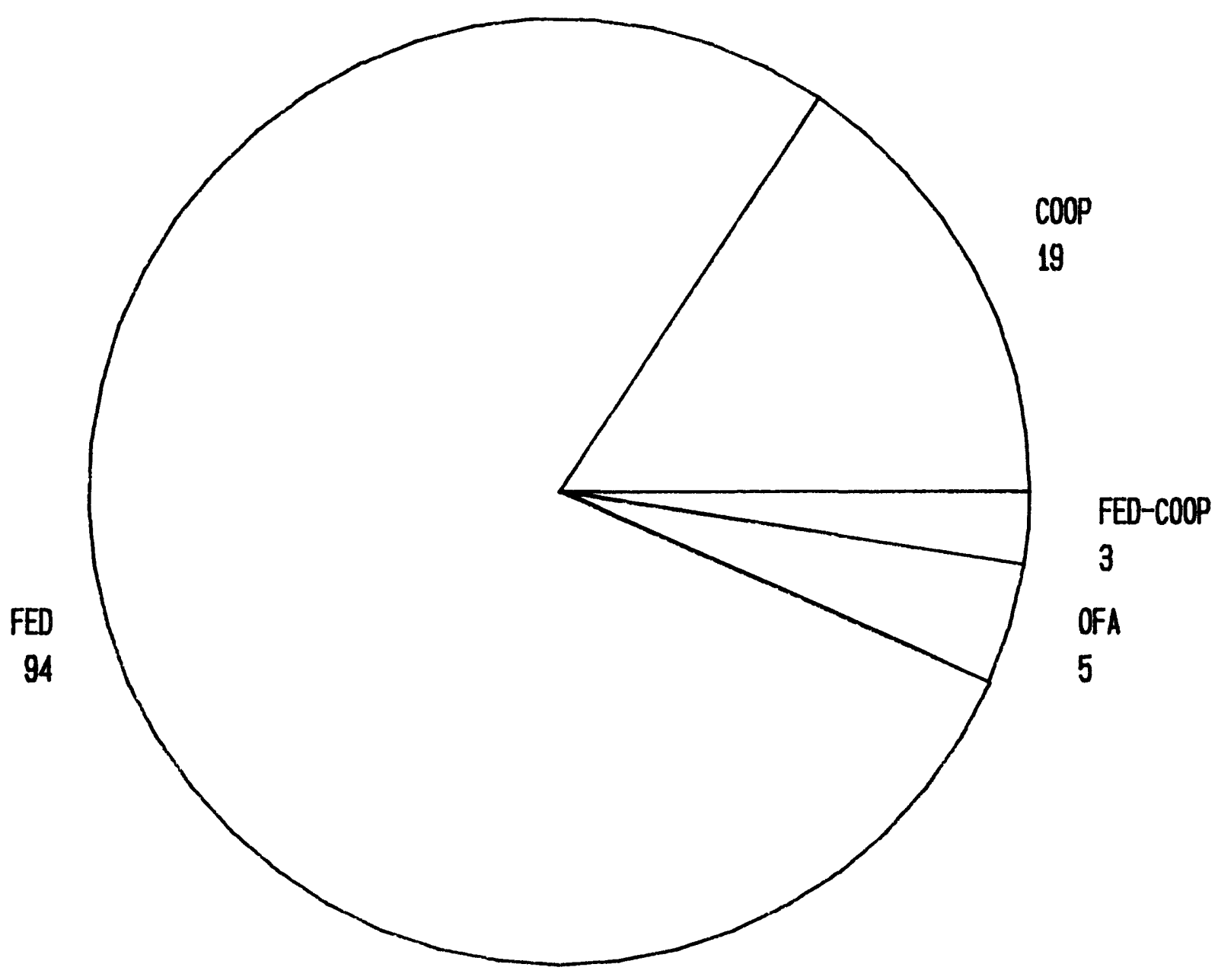

Total Stations $=121$

\section{EXPLANATION:}

\section{SINGLE PROGRAN SUPPORT}

FED = Federal

COOP $=$ Federal-State Cooperative Program

OFA $=$ Other Federal Agencies

\section{CONBINED PROGRAM SUPPORT}

\section{FED-COOP = Federal and Federal-State Cooperative Program}

Figure 23.--Number of precipitation quality stations and the source of funding, fiscal year 1983 . 


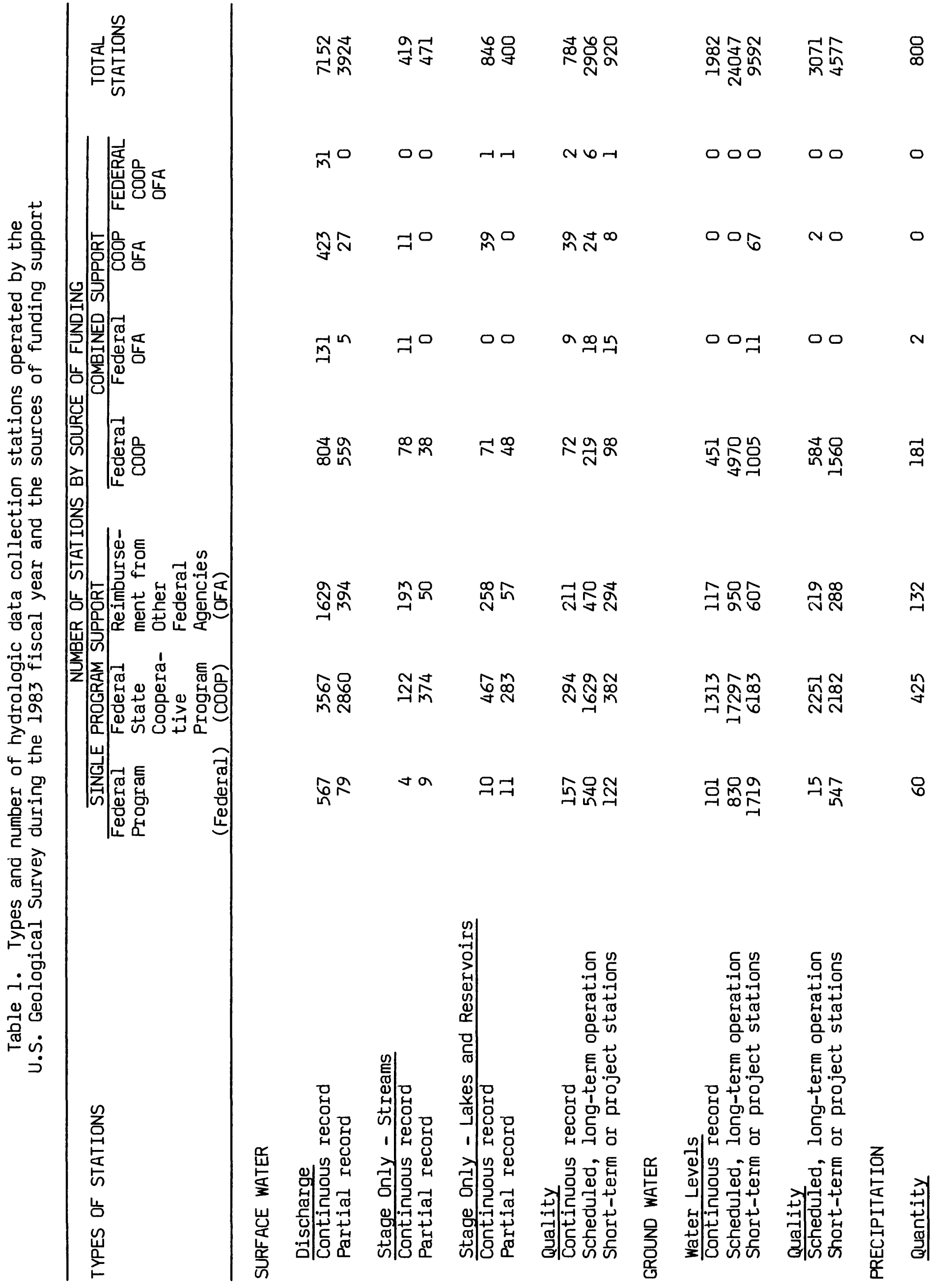




\section{REFERENCES CITED}

Briggs, J. C., and Ficke, J. F., 1977, Quality of Rivers of the United States, 1975 Water Year--Based on the National Stream Quality Accounting Network (NASQAN): U.S. Geological Survey Open-File Report 78-200, $436 \mathrm{p}$.

Gilbert, B. K., and Buchanan, T. J., 1982, Water Data Program of the U.S. Geological Survey: U.S. Geological Survey Circular 863, 16 p.

Solley, W. B., Chase, E. B., and Mann, W. B., 1983, Estimated Use of Water in the United States in 1980: U.S. Geological Survey Circular 1001, $56 \mathrm{p}$. 